\title{
Recikliraj, ideje iz prošlosti: složena priroda recikliranja
}

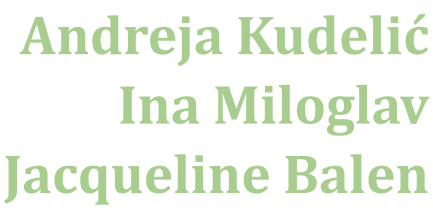

DOI: $10.17234 / 9789531757232-01$

\section{Uvod}

Recikliranje je iznimno složen, ali i univerzalan fenomen bilo da se promatra u sadašnjosti ili u okviru kultura i zajednica iz prošlosti. To je skup društveno-ekonomskih, političkih odluka, ali i religijskih ideologija nekog društva i pojedinaca, no šire razumijevanje toga fenomena u okviru društveno-humanističkih znanosti i dalje je pomalo zapostavljeno. Načini i motivi koji su čovjeka u dalekoj i bližoj prošlosti navodili na popravljanje, ponovnu upotrebu i recikliranje predmeta i/ili materijala duboko su usađeni u različite sfere društva, ali prije svega u čovjeka. U radu će se pojasniti termini i što sve podrazumijeva recikliranje u suvremeno doba u skladu s doživljajem materijalnog danas. Također će se nastojati prikazati primjeri na koji su način naši preci reciklirali materijale, ponovno upotrebljavali predmete te način na koji je taj koncept ugrađen u kulture iz prošlosti. Da bismo razumjeli mehanizme koji utječu na arheološku interpretaciju takvih složenih društvenih fenomena pojasnit će se principi razmatranja takve prakse u okviru arheološke teorije.

Prema definiciji recikliranje podrazumijeva skupljanje upotrijebljenih, tj. korištenih ili odbačenih materijala i transformaciju u njihove sastavne sirovine (https://discardstudies. com/2016/03/09/the-politics-of-recycling-vs-reusing/). Drugim riječima recikliranje je izdvajanje materijala iz otpada i njegovo ponovno korištenje, a ono uključuje skupljanje, razvrstavanje, preradu i izradu novih proizvoda iz iskorištenih stvari ili materijala (https:// hr.wikipedia.org/wiki/Recikliranje). Suvremene kampanje koje promiču recikliranje ističu da se njime može smanjiti količina otpada, nadomjestiti potreba za izvornom sirovinom, smanjiti potrošnja energije, zagađenje zraka i tla (https://discardstudies.com/2016/03/09/the-politics-of-recycling-vs-reusing/). Međutim, recikliranje podrazumijeva nekoliko stupnjeva obrade odbačenih predmeta, odnosno materijala poput: a) tretiranja i obrade odbačenog materijala sa svrhom ponovne upotrebe; b) prilagodbe odbačenog materijala za novu upotrebu bez promjene osnovnog oblika i namjene; c) potpune prerade odbačenog materijala i ponavljanja postupka proizvodnje (http://www.dictionary.com/browse/recycle). U tom smislu suvremeno poimanje recikliranja podrazumijeva i sekundarnu upotrebu, to jest preradu i ponovno korištenje predmeta i materijala. Upravo su primjeri takvih oblika „recikliranja“ zabilježeni od najstarijih razdoblja prošlosti. 
U posljednjih stotinu godina, ljudi su postali izrazito privrženi praktičnosti, raspoloživosti, modi i stalnoj tehnološkoj promjeni, a porast masovne potrošnje doveo je do pojave, ranije nezamislivih količina otpada. U skladu s problemom nagomilanog „smeća“ sustav recikliranja postaje relativno unosan posao, a javnost se raznim kampanjama potiče na sortiranje otpada. Recikliranje i ponovna upotreba prolazili su kroz različite faze i različita značenja za društvo, počevši od industrijske revolucije do povećanog konzumerizma i stvaranja potrošačkog društva. Međutim, u prošlosti ove su aktivnosti imale sasvim drukčije značenje za čovjeka.

Kada je recikliranje postalo globalnim fenomenom? Prema provedenim istraživanjima (više kod: Amick 2015: 4) veliki preokret u poimanju recikliranja, popravljanja, ponovne upotrebe predmeta i materijala dogodio se početkom 20. st. s počecima industrijalizacije. Upravo su te promjene dovele do pomaka u načinu postupanja s oštećenim ili odbačenim predmetima. Praksa popravljanja i ponovne upotrebe zamijenjena je svojevrsnim ranim principom recikliranja (engl. downcycling) pri čemu su odbačeni predmeti podijeljeni na sirovi proizvod ili su ponovno proizvedeni kao novi predmeti (Amick 2015: 5). Značajan trenutak zbio se tijekom Drugoga svjetskog rata u Ujedinjenom Kraljevstvu kada je zbog straha od gubitka potencijalne vrijednosti iz otpada te straha od prijetnje uvozom djevičanske sirovine osnovano Nacionalno vijeće za spašavanje (National Salvage Council) koje je organiziralo aktivnu kampanju propagiranja prakse recikliranja za široke mase kao pomoć u poimanju rata (sl. 1). Cilj je bio pokušati natjerati mase na odvajanje sirovine (otpada) „motivirajući“ ih kroz strah od osobnih gubitaka, strah za vlastiti život i od gubitka slobode. Na taj način gospodarenje otpadom postavljeno je u okvire opće krize, gdje članovi zajednice postaju aktivni dionici misije spašavanja što postaje njihova moralna obaveza i domoljubna dužnost (Wilson 1995: 127; Riley 2008: 81).

Razmatrajući ovaj primjer u konceptualnom smislu (Douglas 1984, prema Riley 2008: 81-82) jasno je da se radi o složenim društveno-ekonomskim, političkim, okolišnim i psihološkim čimbenicima koji su znatno utjecali na tadašnje mase, no poslužili su i kao model za suvremene propagande recikliranja $^{1}$ (Riley 2008: 81).

I dok je ekonomija u prvoj polovini prošloga stoljeća uslijed ekonomske krize i rata u otpadu vidjela veliku vrijednost, u suvremeno doba recikliranje se aktivno dovodi u vezu sa širom, nacionalnom i globalnom brigom o okolišu. Od 60-ih godina prošloga stoljeća potreba za smanjenjem otpada, koja se manifestirala kroz promoviranje recikliranja, polako je utirala put prema programima zaštite okoliša i gospodarenja otpadom na globalnoj razini (Gandy 1994). Današnje poimanje recikliranja i ponovne upotrebe isključivo je vezano za pojmove poput održivog razvoja, smanjenja otpada, gospodarenja otpadom, gospodarskog razvoja te brige za zaštitu okoliša. Propaganda 21. st. uglavnom je svedena na tri poruke: smanjiti, reciklirati, ponovno upotrijebiti (eng. reduce, reuse, recycle) koje su sinonimi modernog društva za brigu o okolišu u smislu uštede novca, energije i prirodnih resursa.

Praksa je pokazala da su takvi ideološki i politički poticaji najbolji pokretači da konzumenti, tj. javnost, ali i pojedinci sortiraju otpad (Amick 2015: 5). Istraživanja su također pokazala da individualno sortiranje otpada u suvremeno doba, u okviru razvijenih zemalja, provode najsiromašnije društveno-ekonomske klase (Wilson 1995: 127-128; Amick 2015), a nešto što bi bilo najbliže kulturi prenamjene i ponovne upotrebe stvari prakticiraju najsiromašniji slojevi građanstva (obično ih nazivaju skupljači otpada) nerazvijenih država trećega svijeta ${ }^{2}$ (Medina 2007).

\footnotetext{
1 To se odnosi na tri međusobno povezana pristupa: strukturirani i ciljani publicitet, prihvaćanje takvog publiciteta od strane publike te metode i tehnike uključene u povećanje tog prihvaćanja. (Riley 2008: 82).

${ }^{2}$ Prema posljednjim procjenama oko 140 milijuna ljudi (2\% ljudske populacije) preživljava od skupljanja i sortiranja otpada, a većinu ih čine žena i djeca što negativno utječe i na njihovo zdravlje (Medina 2007).
} 
Neki pak smatraju da je globalna osviještenost i interes javnosti za recikliranjem nastala i kao osjećaj krivnje zbog povećane stope konzumacije i povećanja proizvodnje otpada (Hawkins 2006). Također je zabilježeno da u razvijenom svijetu najviše reciklira starija populacija, pa tako i u Hrvatskoj, što se dovodi u vezu s još uvijek živućim nasljeđem iz razdoblja nakon Drugoga svjetskog rata (Barr et al. 2005). Ipak, recikliranje, za one u razvijenom svijetu, predstavlja jednostavno razvrstavanje otpada, po mogućnosti ispred vlastitog doma. Evidentno je da takvo razvrstavanje otpada predstavlja obvezu koju su vladajuće strukture i industrija prebacile na javnost kako bi se oslobodili povećanih troškova recikliranja materijala na marginama profitne industrije (Dean 1995; Eckelman \& Chertow 2009, prema Amick 2015: 5), a porukama o očuvanju okoliša motiviraju one koji sortiraju, odnosno recikliraju.

Ako pođemo od glavnog „montiranog“ pokretača koji ipak predstavlja pozitivnu misao vodilju, tada bi valjalo težiti smanjenju količine ambalaže, ulaganju u obnovljive izvore energije, osvještavanju negativnih posljedica masovnog konzumerizma, poticanju dizajniranja predmeta koji su popravljivi, dugotrajni, sigurni te poticanju na brigu o predmetima i popravljanju stvari. Navedeno podrazumijeva ne samo mijenjanje prakse upotrebe, već i proizvodnje što bi u konačnici znatno utjecalo na globalnu ekonomiju i politiku, a tek onda pozitivno na društvo i okoliš.

I dok se pozadina suvremene prakse recikliranja odnosi na smanjenje otpada te brigu o očuvanju okoliša, kada govorimo o prošlosti može se reći da je sustav recikliranja čovjeku urođen. Međutim, u prošlosti ove su aktivnosti imale sasvim drukčije značenje za čovjeka jer je svijest o ekološkim problemima vezana za suvremeni način života te je sastavni dio globalnih ekonomskih i političkih zbivanja. Ponovna upotreba predmeta, odnosno njihova prenamjena pokazatelj je kultura koje ne odbacuju predmete nego teže kulturi ponovne upotrebe stvari, a upravo o tome možemo mnogo naučiti iz prošlosti.

\section{Recikliranje i arheološki kontekst}

Recikliranje je u prošlosti zabilježeno u gotovo svim segmentima ljudskog društva, od recikliranja svakodnevnih stvari načinjenih od različitih materijala (keramika, staklo, kosti, kamen, bronca, željezo, tekstil, drvo) do „recikliranja“ određenog prostora (kuće, naselja, sveta mjesta). Međutim, prepoznati aktivnosti vezane uz recikliranje u prošlim kulturama kao i otkriti te rastumačiti zapise ponovne ili sekundarne upotrebe na arheološkom materijalu vrlo je složeno, a tumačenje nerijetko ovisi i o kontekstu u kojem su artefakti pronađeni.

Raspravljati o recikliranju ne može proći bez razmatranja smeća stoga je ovdje važno spomenuti znanost o smeću (eng. garbology), znanstvenu disciplinu koja se u okviru antropoloških, suvremenih ekoloških studija i arheologije razvila još sedamdesetih godina prošlog stoljeća u Americi. Projekt Smeće (The Garbage Project) prof. W. Rahtje započeo je na Sveučilištu u Arizoni s ciljem proučavanja otpada, odnosno potrošačkih navika Amerikanaca. Glavna ideja projekta bila je premisa: ono što su ljudi posjedovali te potom bacili pruža nam mnogo više informacija o životima kakve su vodili nego što bi oni sami to mogli. Tradicionalne arheološke metode primjenjene su na suvremene arheološke situacije - deponije smeća. Takav pristup omogućio je stvaranje platforme za bolje razumijevanje onoga što se doista dogodilo s otpadom na razini domaćinstva. Rezultati takvih istraživanja glavni su izvor informacija o prirodi i promjenama obrazaca bacanja smeća u suvremeno doba, što je primjenjivo i na razmatranje otpada u arheološkom kontekstu (Rathje \& Murphy 2001).

S druge strane, u sklopu bihevioralne arheologije definicija recikliranja, ponovne i sekundarne upotrebe teorijski je vrlo detaljno razmotrena prije 30-ak godina (Schiffer 1983; 1987), pri čemu su promatrani različiti procesi u kojima artefakti ulaze u arheološki zapis, a posljedica su različitih aktivnosti. Kada se predmet razbio, istrošio ili iz drugih razloga više nije imao svoju utilitarnu ili simboličku funkciju, otvarale su se mogućnosti za njegovu ponovnu upotrebu. Za 
potrebe tumačenja životnog vijeka predmeta u arheologiji Schiffer (1987: 32; Schiffer 2010: 33) predlaže četiri vrste procesa ponovne upotrebe: lateralno ili kružno cirkuliranje, recikliranje, sekundarna upotreba i proces konzerviranja. Lateralno ili kružno cirkuliranje (eng. lateral cycling) uključuje isključivo promjenu korisnika predmeta ili društvenu jedinicu korištenja, a da se pritom oblik predmeta i njegova funkcija ne mijenjaju. Takvu vrstu ponovne upotrebe vrlo je teško identificirati arheološki i to zato jer se karakteristike predmeta takvim procesima ne bi promijenile (npr. prodaja rabljenih predmeta, buvljak, eng. Flea Market i sl.). S druge strane recikliranje (eng. recycling) podrazumijeva da predmeti nakon nekog vremena upotrebe budu vraćeni u proizvodni postupak što podrazumijeva promjenu oblika predmeta, ali i funkcije (npr. oštećena kamena sjekira može se preraditi u neko drugo oruđe). Ponekad recikliranje ne uništi u potpunosti tragove prethodnih, odnosno originalnih, procesa proizvodnje i upotrebe, a to je osobito važno i često vidljivo na arheološkim artefaktima. Sekundarna upotreba (eng. secondary use) je promjena funkcije predmeta, a da se pritom ne mijenja njezin oblik (npr. istrošeni kameni žrvanj može se koristiti kao nakovanj ili predmeti svakodnevne upotrebe često postaju dio pogrebnog rituala i polažu se uz pokojnika). Tzv. procesi konzerviranja (eng. conservatory processes) četvrta su vrsta procesa ponovne upotrebe predmeta, a predstavljaju različite tipove sekundarne upotrebe koja ponekad rezultira dugoročnim očuvanjem, a ovoj skupini pripadaju premeti čija je priroda uglavnom simbolička (npr. pokloni, priznanja i uspomene).

Artefakti su mogli imati više funkcija. Kada neki predmet više nije bio funkcionalan ni u kojem obliku (popravljen, dorađen ili djelomično prenamijenjen) tada takav predmet postaje dio arheološkog konteksta, a taj proces uključuje nekoliko faza deponiranja, transportiranja (pod utjecajem čovjeka i/ili prirode) te u konačnici postaje otpad (Schiffer 1987: 47). Nerijetko se događa da i takav predmet u nekom potpuno drukčijem kontekstu bude vraćen u „život", odnosno ponovno korišten. Na primjer, arheološki nalazi otkriveni iskopavanjima postaju dijelom kulturne baštine, dio su muzejskog postava, služe za edukaciju, znanstvene analize i sl. Može se reći da predmeti imaju društveno, simboličko i ekonomsko značenje koje nije statično, a biografija predmeta ne umire kada se on istroši ili razbije (Kopytoff 1986; Dooijes \& Nieuwenhuyse 2007). Dakle, postoji čitav spektar različitih mehanizama koji utječu na životni vijek predmeta. Taj životni vijek u osnovni je nepredvidiv, međutim pojedine faze toga ciklusa moguće je rekonstruirati.

Recikliranje i ponovna upotreba u prošlosti vezane su uz složeni odnos između čovjeka i okoliša, i čovjeka i predmeta, a u okviru takvih složenih veza recikliranje predstavlja sastavni dio tehnologije proizvodnje i upotrebe predmeta. Ono je dio lanca operacija te odražava načine ponašanja onih koji predmete izrađuju, popravljaju, mijenjaju im funkciju ili ga recikliraju. Proučavanje procesa proizvodnje, upotrebe, ponovne ili sekundarne upotrebe i recikliranja omogućuje nam bolje razumijevanje društveno-ekonomskih i religioznih aspekata života u prošlosti. Ono također ukazuje na određene aspekte tradicije i društvenih ideologija te omogućuje stvaranje osnovanih pretpostavki o ponašanju pojedinaca, tj. zajednica. Stoga se u nastavku teksta predstavlja niz primjera „recikliranja“ iz prošlosti koji su postavljeni u interpretativnoideološke okvire, koji su mogli biti pokretači takvog ponašanja ili je svojevrsni princip recikliranja mogao izravno utjecati na društvene ideologije.

\section{Materijali kao dio energetske učinkovitosti}

Čovjekova sposobnost da iskoristi i prilagodi materijale iz prirode vlastitim potrebama sa svrhom preživljavanja univerzalna je. Osim toga, sposobnost stvaranja novih materijala kao i inovativnost predstavljaju svojevrsnu (r)evoluciju u razvoju ljudskog društva. Ljudska egzistencija često je ovisila o materijalima, njihovoj dostupnosti i vještini majstora koji su predmete izrađivali. 
SI. 2: Kamena sjekira s rupom za nasad i polomljena sjekira istog tipa prenamijenjena u čekić, Samatovci, sopotska kultura, mlađe kameno doba (fotografirao: I. Krajcar, Arheološki muzej u Zagrebu).
SI. 3: Kameno dlijeto te kameno dlijeto iskorišteno kao sirovina za izradu sječiva, Samatovci, sopotska kultura, mlađe kameno doba (fotografirao: I. Krajcar, Arheološki muzej u Zagrebu).
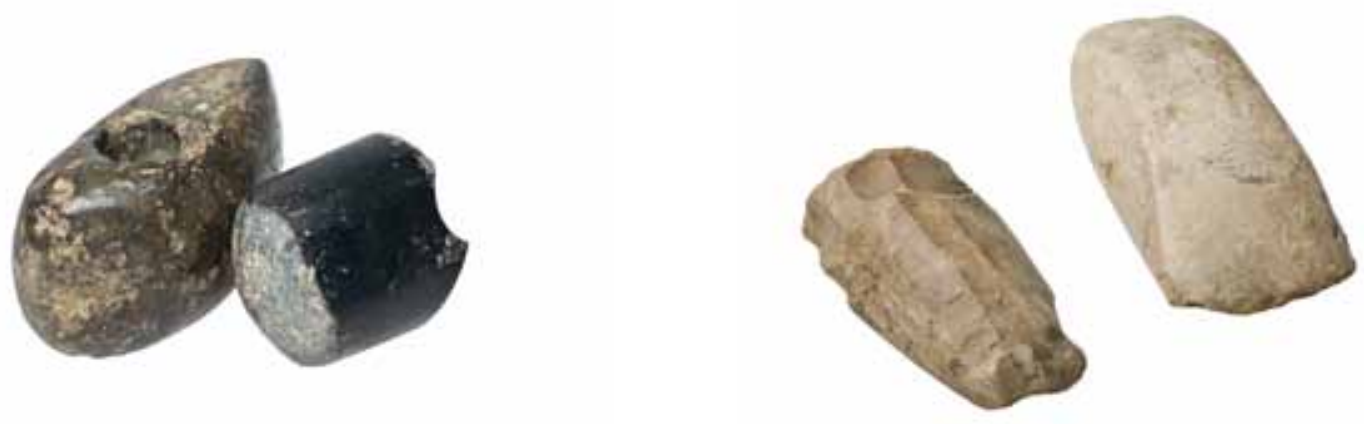

Iako je čovjek u prošlosti koristio različite prirodne materijale najučestaliji materijali koje arheolozi pronalaze arheološkim iskopavanjima jesu: keramika (glina), kost, kamen, dok su umjetni materijali poput stakla i metalnih legura nešto rjeđi što naravno ovisi o tome koje razdoblje prošlosti se istražuje. Upravo se na takvim izdržljivim materijalima vide pokazatelji upotrebe i trošenja (engl. use-wear), popravaka, sekundarne upotrebe ili recikliranja materijala. Predmeti načinjeni od organskih materijala poput tekstila, kože i drva u arheološkom kontekstu rijetko se pronalaze zbog podložnosti brzom propadanju, stoga o praksi recikliranja takvih predmeta imamo mnogo manje saznanja. Sve navedene sirovine korištene su za izradu čitavog spektra predmeta za svakodnevnu upotrebu. Sirovinom su uglavnom vladali vješti pojedinci, majstori ili specijalizirani obrtnici. Glavni razlog učestale prakse popravljanja, prenamjene ili recikliranja predmeta, $\mathrm{tj}$. sirovine, bio je praktične prirode, a u fokusu je bila maksimalna iskoristivost sirovine kao posljedica ograničenih resursa ili njihova ograničena dostupnost.

Jedan od najznačajnijih materijala na kojemu počiva ljudska civilizacija jest kamen, odnosno sposobnost čovjeka da kamen prilagodi svojim potrebama što je znatno utjecalo na tijek ljudske prošlosti. Trajnost, kvaliteta, ali i „narav“ takvog materijala omogućile su nam da dokumentiramo razne faze prenamjene koje su zapisane na njihovoj površini. Razvojem tafonomije koja podrazumijeva proučavanje različitih faza nastanka oblika nekog predmeta to je donekle i omogućeno. Poznato je da tehnologija lomljenog kamena ima raznolike načine produljivanja životnog vijeka nekog predmeta i to kroz oštrenje, dorađivanje i recikliranje. Još prije stotinu godina razvijena je metoda koja je omogućila bilježenje podataka o popravcima i doradi litičkih alatki i to uglavnom kroz fenomen poznat kao "dvostruka patina" što znači da je neki oštećeni artefakt nanovo dorađen i upotrijebljen (Martin 1906, prema: Amick 2015: 6). Tako prikupljeni podaci dokazali su da je praksa popravljanja bila zastupljena vrlo rano u prošlosti i to na artefaktima iz donjega paleolitika (Amick 2015: 6). Mnogi kasniji primjeri dokaz su da je takva praksa bila uobičajena, a pretpostavlja se da je glavni razlog bila laka dostupnost provjereno kvalitetnog materijala.

Jedan od brojnih primjera sekundarne upotrebe kamenih predmeta jesu kamene sjekire iz mlađega kamenog doba. Na primjer, takve sjekire, nakon što su bile polomljene, pretpostavlja se upotrebom, prenamijenjene su te postaju udarači/čekići (sl. 2) dok su pojedine sjekire, odnosno dlijeta postale sirovinom za izradu sječiva (sl. 3) koje se potom moglo uglaviti u drveni 


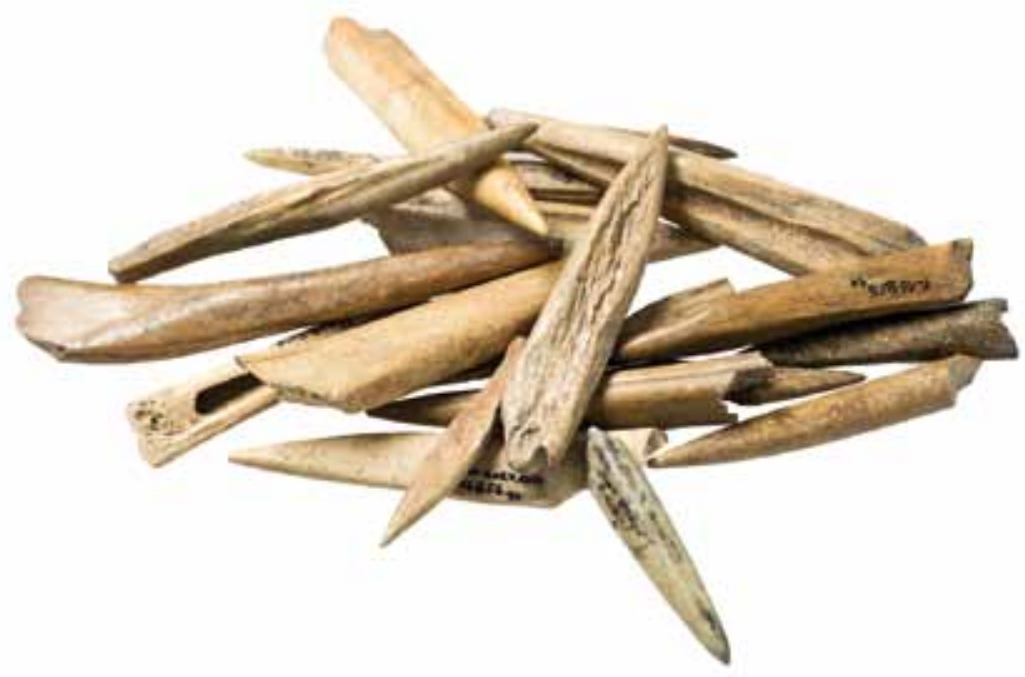

SI. 4: Oruđe napravljeno od kosti životinja, Jakovo-Kormadin, vinčanska kultura, mlađe kameno doba (fotografirao: I. Krajcar, Arheološki muzej u Zagrebu).

držak i služiti potpuno drukčijoj svrsi. U tom smislu može se pretpostaviti ponašanje poput svjesne selekcije odbačenog materijala, kao i praksa skupljanja odbačene litike i kamenih alatki (ponekad iz starijih razdoblja) te njihova prerada i ponovna upotreba u kontekstu mlađih razdoblja prošlosti.

Nalazi životinjskih kostiju u sklopu ostataka naselja uglavnom su produkt konzumacije hrane. Postupak obrade mesa i ostalih životinjskih ostataka poput iznutrica, kože i kostiju od daleke prapovijesti predstavljao je skup složenih društvenih obrazaca ponašanja kakvi su zabilježeni i u našoj, ne tako dalekoj prošlosti (npr. kolinje/ svinjokolja) kao i na mnoštvu primjera iz etnoloških izvora. Dostupnost kosti kao prikladne sirovine za proizvodnju oruđa i sličnih predmeta ovisila je o tri čimbenika: različitim životinjskim vrstama unutar razumne udaljenosti u okviru određenog životnog područja, relativnoj količini kostiju u usporedbi s drugim resursima (npr. kamen, školjka ili drvo) i sposobnosti čovjeka da prepozna kost kao resurs (Olsen 1984). Razmjeri iskorištavanja takve sirovine ovisili su i o okolišnim čimbenicima. Koštane sirovine arheološki su zabilježene još vrlo rano u prapovijesti i potječu iz donjega paleolitika. Osim toga iz etnografskih izvora doznajemo da su predindustrijske zajednice povezivale životinje sa specifičnim moćima ili su im pridavale određene karakteristike (poput snage, lukavosti, agresivnosti i sl.) pa tako i njihovim nusproduktima (Olsen 1984). Obrada kostiju, njihova priprema i transformacija u iskoristivu sirovinu, zahtijevala je posebnu vještinu, a ako pretpostavimo i njima pripisana simbolička svojstva onda ne iznenađuje činjenica da se velik broj koštanih predmeta nakon oštećenja popravljao, dorađivao te ponovno koristio (sl. 4). Na sličan način kao i bilježenje tragova upotrebe i popravaka na litičkim predmetima mogu se dokumentirati i oni na kostima. Međutim, kost također predstavlja potencijalno opasan otpad, ako se promatra u kontekstu života ranih hominina i stalne opasnosti od grabežljivaca koji su otpad vrlo lako mogli nanjušiti i približiti se čovjeku. Stoga je razlog njihove rane upotrebe možda bio motiviran isključivo praktičnim razlozima. $S$ druge strane simbolička komponenta kosti kao sirovine za izradu određenih predmeta također je mogla bitno utjecati na njihov odabir. U tom smislu zanimljiv je podatak, proizišao iz istraživanja koštanih predmeta iz mlađega kamenog doba, da za izradu koštane žlice od kosti goveda treba mnogo više vremena (25 sati) nego što bi to bilo potrebno da se predmet izradio od nekog drugog materijala (Sidéra 2013; Dekker 2014; Vitezović 2016). 
SI. 5: Keramička posuda ukrašena bijelom pastom koja sadrži usitnjene spaljene kosti, lokalitet Beli Manastir - Širine, kultura transdanubijske inkrustirane keramike, rano i srednje brončano doba (fotografirao: I. Krajcar, Arheološki muzej u Zagrebu).

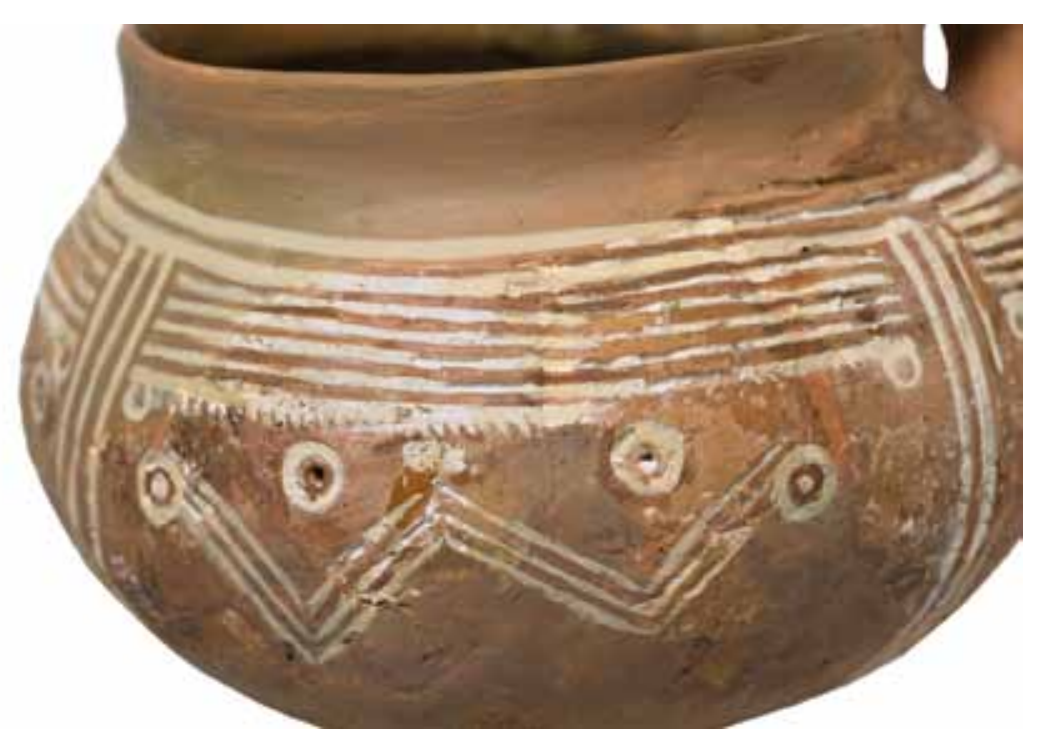

Spomenut ćemo ovdje i jedan neobičan primjer „recikliranja“ kosti, koji je bio vrlo česta prakse tijekom brončanog doba na prostoru Europe. Od mješavine vapnenca, gipsa ili kaolina i kosti pripremala se bijela pasta (inkrustacija) (Roberts et al. 2008; Všianský et al. 2014) kojom su popunjavane brazde načinjene na površini keramičkih posuda čime se postizao kontrastni efekt izražen kroz paletu složenih motiva (sl. 5). Iako se takav efekt mogao postići i bez upotrebe kostiju zabilježeno je da su se spaljene kosti (nije poznato jesu li kosti životinjskog ili ljudskog podrijetla) gotovo tradicionalno koristile za dekoriranje keramičkih posuda. Naravno, razloge takvih odabira teško ćemo moći razumijeti, no s velikom vjerojatnošću možemo pretpostaviti njihovu simboličku pozadinu.

Kosti, kao potencijalno biološki opasan otpad, obilno su prisutne u kasnijim razdobljima prošlosti što može biti posljedica korištenja mnogo dostupnijih sirovina ili sirovina jednostavnijih za obradu i proizvodnju istih predmeta. No, one su uglavnom posljedica povećane dostupnosti sirovine uslijed povećanog broja stanovništva, intenzivnijeg izlova i uzgoja životinja, pa samim time i povećane količine otpadnog materijala. S obzirom da kost nije jednostavno uništiti, a priroda materijala je manje sklona propadanju, kosti predstavljaju vrlo znakovit dokaz o pojavi organskog otpada u sklopu naselja u prošlosti.

Najzastupljenija sirovina u naseljima još od mlađega kamenog doba je glinoviti materijal. Od njega su pretežno izrađivane posude koje su pečenjem transformirane u keramiku, gotovo neuništiv materijal, koji čini više od $90 \%$ nalaza na arheološkim lokalitetima. Osim za izradu keramičkih posuda glinovita smjesa služila je pretežno kao građevinski materijal za izolaciju zidova objekata, gradnju peći (npr. krušnih i keramičarskih), ognjišta i slično. Brojni su primjeri iskorištavanja otpada iz naselja pa je tako vrlo učestao primjer ugradnja komada razbijenih keramičkih posuda u temelje peći. Ta praksa je vrlo zastupljena i to u gotovo svim razdobljima prošlosti, a arheološki su takvi primjeri vrlo brojni (sl. 6) (Balen 2005; Karavanić 2009; Đuričić 2014; Vuković 2015).

Zanimljivo je recikliranje gline kao sirovine na primjeru čuvenih pločica s pismom linear B mikenske civilizacije. Na takve tanke pločice, dužine oko $10 \mathrm{~cm}$ urezivani su znakovi s pomoću stilusa u još meku glinu koja se sušila na suncu, a sadržaj pločica uglavnom se odnosio na upravnu službu pa se na njima donose popisi imanja, zaliha hrane, zavjetnih darova božan- 
SI. 6: Detalj temelja glinene peći napravljen od ulomaka razbijenih keramičkih posuda s lokaliteta Vučedol, badenska kultura, kasno bakreno doba (fotografirala: J. Balen).

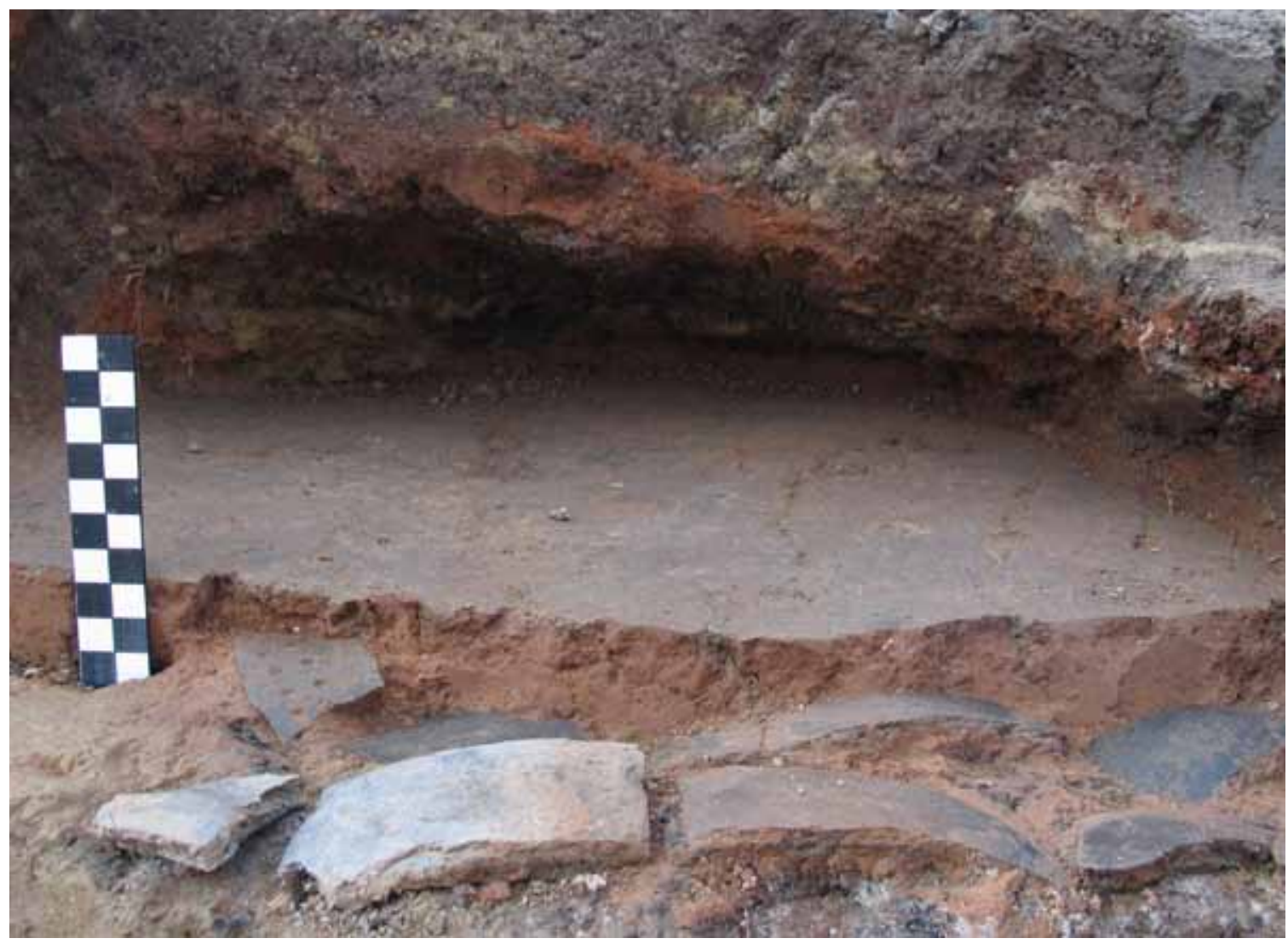

stvima i sl. Pločice s pismom linear B izrađivane su da traju godinu dana pohranjene u arhivi, a nakon toga one su uništene te je sirovina ponovno upotrijebljena za izradu novih pločica s novim zapisima (Kaczmarek 2016).

Rezultati istraživanja provedenih na zapisima linear B pločica iz Pila i luke Vivara jedinstven su pisani dokaz prakse recikliranja brončanih predmeta iz razdoblja između 15. i 12. st. pr. Kr. (Kaczmarek 2016). Naime, na pločicama se mogu iščitati podaci koji ukazuju na praksu popravljanja brončanih posuda (npr. brončani tronožac i brončane posude), ali i defanzivnog tipa oružja (oklop, kaciga) (Kaczmarek 2016). U približno isto doba na prostoru Europe te osobito na području međuriječja rijeka Save, Drave i Dunava znakovita je pojava velikog broja zakopanih, odnosno skrivenih ostava brončanih predmeta ili ostava bronce (Vinski-Gasparini 1973). Arheolozi takve ostave brončanih, uglavnom polomljenih predmeta, tumače na različite načine koji se kreću od utilitarnih do posebnih, simboličkih objašnjenja (Bradley 1988; 2013; Harding 2000). Vjerojatno je riječ o razlozima praktične prirode (predmeti skupljeni kao sirovina za ponovno taljenje), iako iz današnje perspektive ne možemo u potpunosti razumjeti sve razloge donošenja takvih odluka u prošlosti, koje često nisu jednoznačne. Ipak, zapisi ispisani pismom linear B predstavljaju svojevrsni pisani dokaz o svijesti i racionalnom gospodarenju resursima kada je riječ o sirovini, a dodanu vrijednost sirovini u ovom slučaju omogućilo je recikliranje, odnosno obnovljivost pojedinog materijala. 
Jedan od najočitijih primjera recikliranja materijala je „recikliranje“ građevinskog materijala čemu možemo posvjedočiti iz vjerojatno niza vlastitih zapažanja. Jedan od najpopularnijih materijala za recikliranje je kamen i to zbog, već ranije spomenutih svojstava, izdrživosti i dugovječnosti. Eksploatacija kamena, njegova obrada i transport zahtijevaju velike troškove i silne napore, stoga su razlozi upotrebe neiskorištenih kamenih spomenika prije svega bili ekonomske naravi. Jedan od primjera takve reciklaže svakako su brojni srednjovjekovni ruševni burgovi, dvorci, kurije i utvrde koji su doslovno rastavljeni nakon napuštanja ili urušavanja, a uglavnom kamena građa (nerijetko i opeka) preseljenja je i ugrađena u nove objekte potpuno drukčije namjene. Rimskodobni gradovi na Jadranu u kasnoj antici, ali i mlađim povijesnim razdobljima postaju svojevrsni kamenolomi. Kameni spomenici često su pronalaženi izvan njihova originalnog položaja, a građevinski materijal koji je primarno korišten za gradnju utilitarne i sakralne arhitekture, sekundarno se koristi u različite građevinske svrhe (spoliji). U Dalmaciji su npr. ljudi često čišćenjem polja stoljećima razgrađivali arheološki vrijedne ostatke i odlagali ih na kamene gomile. Zabilježeno je također i uništavanje kamenih prapovijesnih gomila, odnosno njihovo "recikliranje" koje se intenziviralo od 19. st. kada je taj kamen korišten za dobivanje amorfnog vapnenca za gradnju suhozida. Gomile su također korištene kao osmatračnice, a vrlo često i kao pastirska skloništa. Zbog lokacije, koja je uvijek bila u vezi sa smjerom pružanja glavnih komunikacijskih putova, gomile su vrlo često korištene i kao strateški vojni položaji. Možda se najbolji primjer nalazi na Biokovu gdje su gomile korištene tijekom Prvoga svjetskog rata tako da se u prapovijesnu gomilu interveniralo gradnjom rovova, osmatračnica za artiljeriju pa čak i manjih, vrlo kvalitetno napravljenih, suhozidnih objekata.

S druge strane, primjeri recikliranja drvene građe, u ne tako davnoj prošlosti, mogu biti dobar pokazatelj sličnih pojava u nama mnogo daljoj prošlosti. Suvremena praksa rastavljanja drvenih kuća jedinstvene tradicijske arhitekture s područja srednje Posavine izgrađenih od hrasta lužnjaka koji se odlikuje tvrdoćom i trajnošću, starih više od stotinu godina, doslovno je izbrisala brojna domaćinstva i dijelove naselja na tom području. No, zabilježeno je da su kuće premještane i u prošlosti iz isključivo praktičnih razloga poput ugroženosti od poplava i sl. (Rajković 2006: 22). S obzirom na vrhunsku kvalitetu građe pretpostavlja se da su i pojedini dijelovi kuća višestruko korišteni tj. reciklirani kroz duži period.

Danas je npr. potražnja za „starom“ opekom vrlo popularna osobito kod uređenja okućnica, gradnje kamina ili rustikalnih interijera ruralnih kuća za odmor. Znakovito je da i danas postoji potreba za recikliranjem građevinskog materijala, no uglavnom se radi o prirodnim materijalima poput drva, opeke ili kamena. Nažalost betonske blokove i iskorištenu metalnu armaturu teško ćemo reciklirati na razini domaćinstva ili za vlastite potrebe. Građevinski otpad danas ${ }^{3}$ predstavlja vrlo velik problem u smislu recikliranja, a prije svega to se odnosi na nepropisno odlaganje te troškove odlaganja i obrade takvog otpada.

Premda se u arheološkom kontekst tekstil pronalazi vrlo rijetko pretpostavlja se da su tkanine i predmeti načinjeni od biljnih vlakana bili podložni svakodnevnom i učestalom popravljanju i recikliranju. Pretpostavka se temelji na vrlo logičnoj premisi, a ona polazi od činjenice da je postupak izrade tkanine iznimno dugotrajan, težak i složen proces, iz današnje perspektive gotovo nezamisliv. Riječ je o postupku koji traje veći dio godine, a tkanine su korištene za čitav niz različitih upotrebnih predmeta. 0 složenosti postupka najviše informacija saznajemo iz etnografskih izvora, no za prapovijesna razdoblja vrlo je teško procijeniti vrijeme potrebno za proizvodnju tekstila. Prema pojedinim eksperimentima, koji su provedeni koristeći se tehnologijom predenja s pomoću pršljenova i tkanja na vertikalnom tkalačkom stanu s utezima, za proizvodnju tkanine od jednoga metra kvadratnog potrebno je otprilike između dva do sedam

${ }^{3}$ U Hrvatskoj se godišnje proizvede više od 2 milijuna tona građevinskog otpada, a kako nije u potpunosti organiziran ekonomski sustav gospodarenja, samo se 5\% građevinskog otpada reciklira ili zbrinjava na prihvatljiv način (http://mplan.hr/djelatnosti/bjelovar/reciklazna-dvorista-i-odlagalista-gradevinskog-otpada). 
dana rada (Andersson 2003; Mazăre 2014: 29). Ako pritom uračunamo postupak uzgoja i obrade biljaka za proizvodnju biljnih vlakana ili obrade životinjske vune i dlake za proizvodnju niti namijenjenih tkanju, riječ je o postupku koji je mogao trajati i znatno dulje. Primjerice, za izradu jedra površine oko $90 \mathrm{~m}^{2}$ za jedan vikinški brod, bilo je potrebno $90 \mathrm{~kg}$ sirovina te $8000 \mathrm{rad}-$ nih sati, a za odijevanje posade od šest do osam članova dodatnih 40-53 kg sirovog materijala te između 2500 i 3300 sati rada (Bender Jørgensen 2012, prema: Bender Jørgensen \& Grömer 2012: 62). Jedan od neprocjenjivih arheoloških izvora za proučavanje odnosa čovjeka prema tkaninama u prapovijesti jesu nalazi iz voda (jezera u alpskoj regiji i sjevernoj Europi), te nalazi iz rudnika soli u Hallstattu pri čemu su uvjeti nalaza utjecali na očuvanost tekstila i odjeće (Bender Jørgensen \& Grömer 2012; Grömer 2016), a upravo je na njima zabilježen niz tragova popravljanja i krpanja tkanina. Iz perspektive suvremenog otpada tekstil je zastupljen sa 3,7\% udjela u ukupnoj količini otpada što je u korelaciji s prošlošću gotovo neusporedivo. Tekstil i predmeti načinjeni od tkanine mogli su se koristiti doslovno do najmanjeg komadića, odnosno do njihova nestajanja. Čini se kako su u prošlosti gospodarski čimbenici kao i optimizacija prirodnih resursa mogli biti glavni motiv za recikliranje tekstila. Prema izvješću o gospodarenju otpadnim tekstilom i obućom (Hrvatska agencija za okoliš i prirodu, Zagreb 2017.) otpadni tekstil i obuća jedna su od najbrže rastućih vrsta otpada danas što je uglavnom posljedica utjecaja modne industrije i sve slabije kvalitete tkanina, a potrošnja tekstila na europskoj razini procjenjuje se da je dvostruka u odnosu na potrošnju prije 20 godina. ${ }^{4}$ Istovremeno tekstil je jedan od najpogodnijih materijala za ponovno korištenje i recikliranje jer čak $90 \%$ tekstilnog otpada može se ponovno upotrijebiti, oporabiti i reciklirati.

\section{Ambalaža nije smeće}

Ambalaža (papir/karton, plastika, drvo, metal, staklo, tekstil) je sve ono što u odnosu na proizvod ima zaštitnu, transportnu, upotrebnu i informativnu funkciju te koja se prije ili tijekom konzumacije proizvoda, odnosno sadržaja, mora odložiti ili odbaciti pa u tom trenutku postaje otpad (http://www.fzoeu.hr/hr/gospodarenje_otpadom/posebne_kategorije_otpada/ambalazni_otpad/). Prvi dio ovog tumačenja pojma može se primijeniti i na ambalažu iz prošlosti, međutim drugi dio, u kojemu se napominje odbacivanje ambalaže, sasvim je prilagođen suvremenom masovnom konzumerizmu, posebice kada je riječ o pohrani hrane. Velika količina komunalnog otpada i reciklažnih materijala proizlazi iz ambalažne industrije, a to su papir i karton (51\%), plastika (19\%) i staklo (29\%) dok ostatak čini ambalažni otpad od metala i drva. ${ }^{5}$ Kada pogledamo navedene podatke karton i plastika predstavljaju najveći udio u ambalažnom otpadu kakvog u prošlosti nije bilo. Na primjer upotreba plastike kao ambalažnog proizvoda radikalno je izmijenila njegov sastav i količinu te je ona, za čitavih $10 \%$, povećala udio otpada po domaćinstvu (Riley 2008: 87).

No, glavna razlika u ambalaži danas i nekada, nije samo u vrsti materijala, nego prije svega $u$ višekratnoj pohrani. Pohrana namirnica u prošlosti uglavnom je bila u vezi s tzv. višekratnom pohranom pri čemu su korištene posude od keramike, a pojedine namirnice pohranjivale su se u drvene sanduke, tekstilne vreće, pletene košare ili u zemlju. Posude su bile trajno namijenjene nekom određenom proizvodu ili namirnici, a i bez etikete bilo je jasno koji se sadržaj pohranjuje u kakvu „ambalažu“ što je u izravnoj vezi sa znanjima o svojstvima namirnica, ali i svojstvima skladišne ambalaže.

4 U miješanom komunalnom otpadu procijenjeni udio otpadnog tekstila (odjeća i obuća, tkanine, tekstilna ambalaža) iznosi $3,71 \%$, a udio u glomaznom otpadu procijenjen je na $4 \%$ (Izvješće o gospodarenju otpadnim tekstilom i obućom, Hrvatska agencija za okoliš i prirodu, Zagreb 2017.).

${ }^{5}$ Plan gospodarenja otpadom RH, podaci za razdoblje od 2016-2022. godine. 
SI. 7: Tragovi popravaka keramičkih posuda: crtež idealne rekonstrukcije popravljene keramičke posude s pomoću konopa i ulomci keramičkih posuda s rupicama (Gorjani-Kremenjača, sopotska kultura, mlađe kameno doba i Damića gradina, vučedolska kultura, kasno bakreno doba) (crtež: M. Rončević; fotografirao: I. Krajcar, Arheološki muzej u Zagrebu).
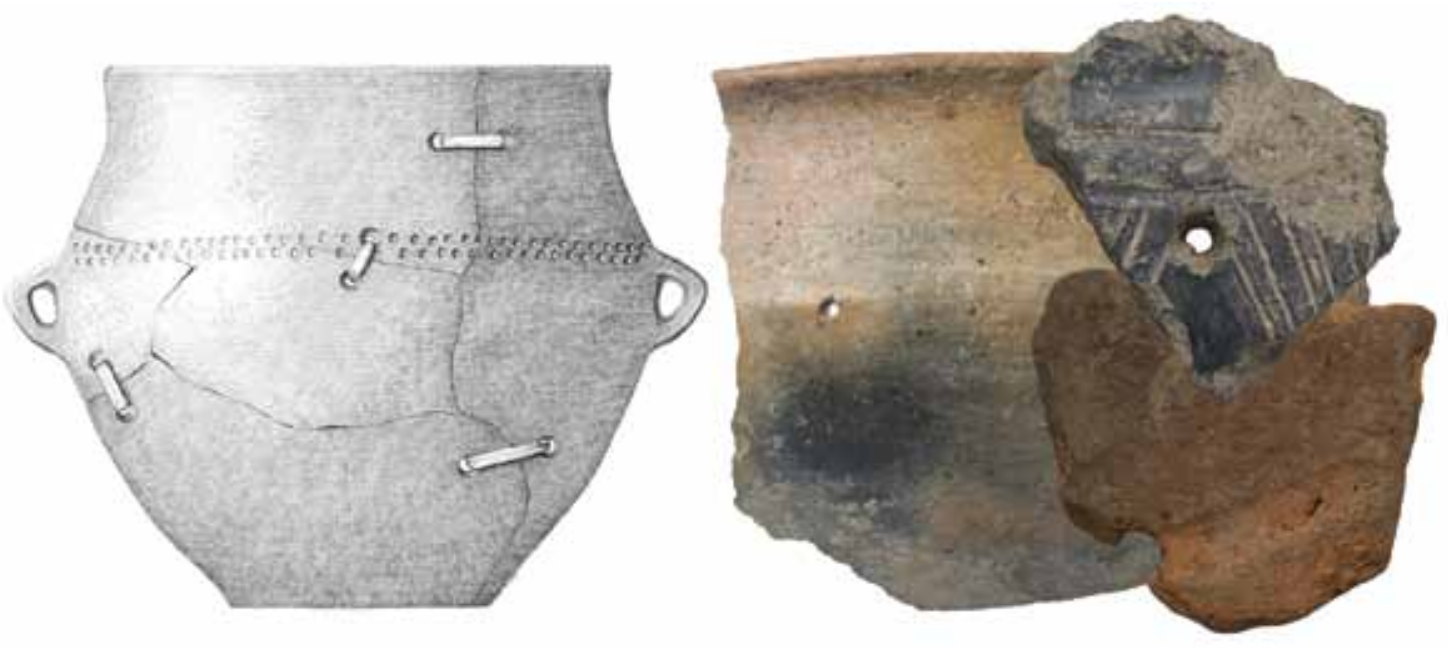

Možda najraniji i najdugotrajniji materijal za pohranu namirnica, ali i za termalnu obradu hrane svakako je bila keramika, odnosno keramičke posude. Proizvodnja keramičkih posuda u prapovijesti uglavnom je bila organizirana na razini domaćinstva ili njih nekoliko, a proizvodnja se provodila sezonski. Praksa korištenja oštećenih ili djelomično razbijenih posuda zabilježena je na arheološkom materijalu i u etnografskim primjerima. Možda najčešće zabilježeni dokazi o popravcima oštećenih keramičkih posuda jest pojava malih koncentričnih rupica na keramičkim ulomcima. Takvo bušenje stijenke keramičke posude na najmanje dva mjesta služilo je za provlačenje organske ili metalne spojnice koja je imala zadaću učvrstiti tijelo posude i onemogućiti posudi da se u potpunosti raspadne. Rupe su u ranim razdobljima prapovijesti bile povezane organskim materijalom poput kože ili konopa (Dooijes \& Nieuwenhuyse 2009: 18). Takvi su popravci zabilježeni i na keramici mlađega kamenog i bakrenog doba s prostora današnje sjeverne Hrvatske (sl. 7), a vrlo često nalazimo ih i na keramici iz starijeg željeznog doba (sl. 8). Zanimljivo je da su takvi popravci mnogo rjeđe zabilježeni ili u potpunosti izostaju

SI. 8: Višestruko popravljana keramička posuda, Sisak, starije željezno doba (fotografirao: I. Krajcar, Arheološki muzej u Zagrebu).

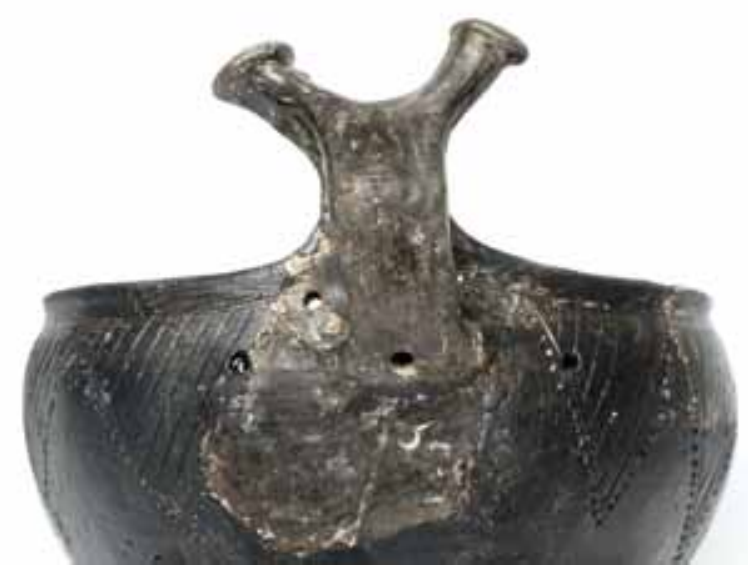


SI. 9: Tragovi popravaka keramičkih posuda: a) ulomak keramičke posude popravljane s pomoću željeznih spojnica, Vukovar- Lijeva bara, mlađe željezno doba (fotografirao: I. Krajcar, Arheološki muzej u Zagrebu); b) ulomak keramičke posude popravljane s pomoću olovnih spojnica, Ulica kralja Zvonimira 12, Vinkovci, rimsko doba (fototeka Gradskog Muzeja Vinkovci).

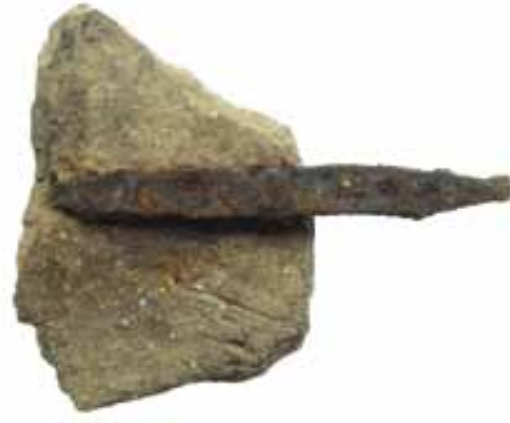

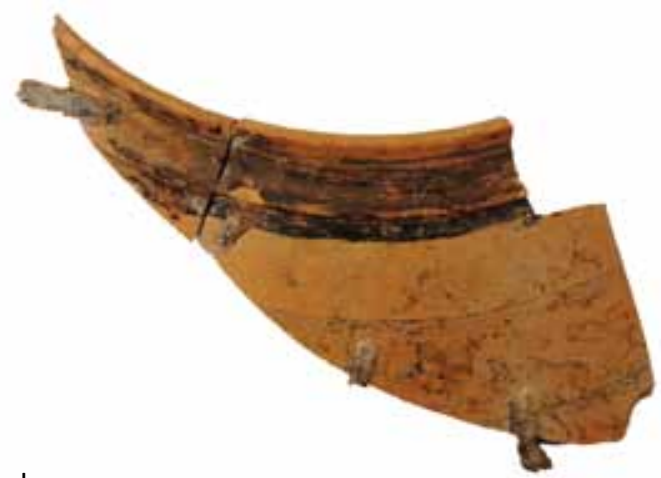

b

na posudama iz brončanoga doba. U kasnijim razdobljima rupe su bile povezane žicom te metalnim ili olovnim spojkama (sl. 9a, 9b) što je bila uobičajena praksa u rimsko doba. Međutim, popravci na keramičkim posudama nisu vidljivi samo u obliku povezanih rupa, već su komadi polomljene keramičke posude bili lijepljeni bitumenom te vapnom tj. gipsom (primjer iz Sirije, 7. i 6. tisućljeće pr. Kr.) (Dooijes \& Nieuwenhuyse 2007) ili smolom brezove kore (Grčka, druga pol. 6. tisućljeća pr. Kr.) (Urem-Kotsou et al. 2002). Na taj način omogućeno je ponovno korištenje iste posude, stoga su takvi popravci pokazatelj promjene funkcije posuda. Npr. posuda koja je izvorno služila za kuhanje mogla se ponovno koristiti kao posuda za skladištenje suhih namirnica. Možda najbolji primjer ponovne upotrebe keramičkih posuda zabilježen je na amforama zbog njihove masovne proizvodnje i upotrebe. Nakon istrošenosti ili lomljenja amfore su služile za mnoge sekundarne upotrebe, kao npr. za skladištenje suhih namirnica poput usoljene ribe, leće, grožđa, smokvi, raznih žitarica, brašna, maslina zatim kao spremišta za sirovinu, dijelovi dna koristili su se kao poklopci ili čepovi (za pregled vidi: Peña 2007), a koristile su se i kao

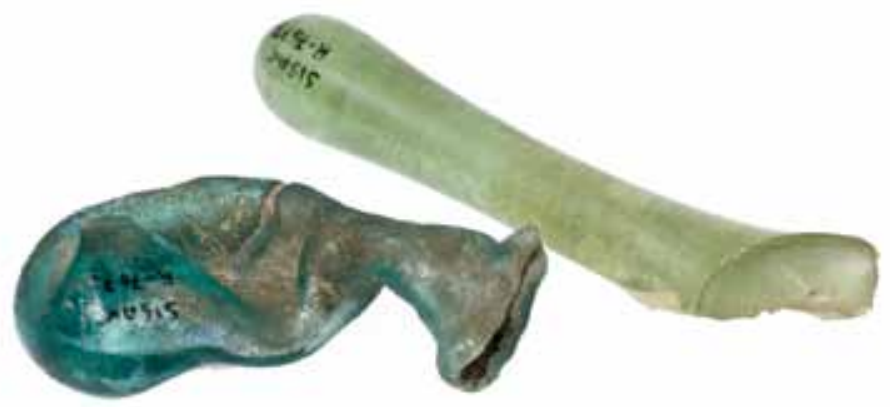

SI. 10: Balzamarij - neuspjeli proizvod koji ponovno ulazi u proces izrade, Sisak, rimsko doba (fotografirao: I. Krajcar, Arheološki muzej u Zagrebu). 
građevinski materijal. Na lokalitetu Villa Regina u blizini Pompeja zabilježeno je vrlo zanimljivo korištenje donjeg dijela amfore koji je služio za uriniranje (Peña 2007: 139-140, fig. 6.4). Svi navedeni primjeri recikliranja keramičkih posuda uglavnom su praktične prirode koji uključuju svakodnevno susretanje s materijalima kojima se uvijek mogla pronaći neka nova funkcija. Međutim, razlozi za popravak keramike mogli su biti različiti, ovisno o vremenu i mjestu, a osnovni motivi recikliranja keramičkih posuda mogu se podijeliti u nekoliko općih kategorija: funkcionalni, estetski, ekonomski i simbolički. Neke posude imale su posebno značenje za zajednicu i zato su takve posude češće popravljane što spada u sferu simboličke reciklaže o kojoj će biti više riječi u zasebnom poglavlju.

Staklo je umjetni materijal stvoren iz prirodnih sirovina (dobiva se taljenjem osnovnih sirovina: kvarcnog pijeska, sode i vapnenca), izumljen još u prapovijesti. Otad se tehnologija proizvodnje usavršavala, a time se i repertoar predmeta načinjenih od ovog materijala povećavao, čime je postajao sve češći inventar u domaćinstvima. Danas staklena ambalaža u prosjeku čini $3,7 \%$ otpada jednog domaćinstva, a na godišnjoj razini u svijetu se proizvede 100 milijardi staklenih boca. ${ }^{6}$ Međutim, staklo je jedan od rijetkih materijala koji se može beskonačno reciklirati i ponovno koristiti. Iako je njegova proizvodnja bila poznata još u Egiptu i Mezopotamiji (Rasmussen 2012: 11), praksa recikliranja stakla može se sa sigurnošću potvrditi tek od prvoga stoljeća. Staklo se koristilo za izradu posuda (čaša, zdjela i sl.) te kao građevinski materijal (npr. mozaici i stakla).

Praksa recikliranja stakla u prošlosti usvojena je vjerojatno iz tehničkih i ekonomskih razloga poput nedostatka sirovine i smanjenih troškova proizvodnje (Keller 2005). Možda najbolji dokazi o organiziranom i masovnom recikliranju stakla otkriveni su u brodskim olupinama na dnu mora i to iz različitih razdoblja prošlosti, a koji su prevozili, ponekad i više tona, razbijenog i otpadnog stakla (eng. cullet) namijenjenog recikliranju (Silvestri 2008; Bass et al. 2009). U arheološkom kontekstu predmeti koji su mogli biti reciklirani pojavljuju se i kao poluproizvodi, čija proizvodnja iz nekog razloga nije uspjela pa sam predmet ponovno ulazi u proces izrade (sl. 10). Rimsko staklo i danas je izuzetno cijenjeno i nastavlja se ponovno upotrebljavati za npr. izradu nakita (Freestone 2015: 39), a na sličan način recikliralo se i staklo iz najmlađih razdoblja prapovijesti (Franjić \& Freestone 2017) što na neki način svjedoči o kontinuitetu njegove upotrebe.

\section{Reguliranje recikliranja i ekonomska održivost}

U arheološkom smislu tzv. rimsko doba ostavilo je mnoštvo materijalnih tragova i u potpunosti je izmijenilo tijek ljudske prošlosti na razini svih sfera društva, a jedan od najsnažnijih aspekata širenja rimske kulture je graditeljstvo. Urbanizacija je u tom smislu znatno utjecala na problem odlaganja otpada, a zanimljiv je i primjer prvih tzv. sanitetskih jedinica u Rimu, što podrazumijeva ljude koji su prolazili gradom i na kola tovarili krupniji otpad te ga iznosili iz Rima i odlagali u jame. Najraniji pisani dokazi o planskom i organiziranom recikliranju građevinskog materijala potječu također iz Rimskog doba. Razina društveno-političke organizacije, birokratizacija i ekonomska održivost glavni su okviri unutar kojih se prvi put donose zakoni i propisi o planskom recikliranju građevinskog materijala. Naime, njima su država i lokalna uprava nastojale uvesti red u graditeljstvo, rušenje zgrada, ali i ponovno korištenje građevinskog materijala i arhitektonskih elemenata o čemu postoje konkretni zapisi (Marano 2011: 141-145). Čak su propisane i kazne za ne poštivanje propisa i zakona (Lepore 2010: 79-80) što je dobar pokazatelj učestalosti zlouporabe i svijesti vlasti o dragocjenosti sirovine (uglavnom mramora), ali i arhitektonske kulturne baštine. To je osobito snažno izraženo u kasnocarskom

${ }^{6}$ Prema podacima Fonda za zaštitu i energetsku učinkovitost. 
periodu (od druge polovine 3. st.) kada se i zbog opće krize javna izgradnja prebacila na lokalnu vlast čime se recikliranje i gospodarenje građevinskim materijalom (otpadom) intenziviralo s ciljem racionalizacije troškova gradnje.

Međutim, zabilježeni su još stariji zapisani dokazi o praksi recikliranja materijala. Naime, riječ je o recikliranju brončanih predmeta darovanih božanstvima u sklopu brojnih hramova mikenske kulture na Mediteranu. Jedan od argumenata koji istraživači ističu jest nedostatak metalnih artefakata u votivnim jamama uz svetišta te nepostojanje ostava koje su sastavljene isključivo od predmeta koji se mogu identificirati kao votivne ostave. Pretpostavlja se da je tijekom kasnoga brončanog doba dio brončanih votivnih predmeta bio recikliran, a ne deponiran kao votivni dar (Karageorghis \& Kassiandiou 1999). Tako Cadwick (1974: 142, prema Karageorghis \& Kassiandiou 1999: 184) pretpostavlja da su svetišta na Cipru u kasnome brončanom dobu puna dotrajalih brončanih predmeta te da su vlasti naložile njihovo recikliranje, osobito u trenutku kada je to bilo nužno što se može dovesti u vezu s povećanom potražnjom za sirovinom ili trenucima svojevrsne ekonomske krize. Kasnije i drugi autori argumentirano te načelno podupiru ovu teoriju donoseći dokaze o recikliranju bronce u mikenskoj kulturi (Muhly 1992; Smith 1992-1993; prema: Karageorghis \& Kassiandiou 1999: 184). Autori se osobito pozivaju na transkripcije zapisa Linear B pisma, ali i učestale nalaze troske u ostavama bronce (Muhly 1992; Karageorghis \& Kassiandiou 1999; Kaczmarek 2016). Međutim, iako se načelno može pretpostaviti da su hramske bronce reciklirane, još uvijek ne postoje dokazi koji bi mogli ukazati na to je li takva praksa bila uobičajena, odnosno učestala ili se ona dovodi u vezu s razdobljima ekonomske krize (Karageorghis \& Kassiandiou 1999: 185).

Zapisi o recikliranju ekonomski značajnog resursa, bilo da se radi o propisima, zakonima ili samo o navođenju takve prakse u okviru uprave razvijenih društava, daju sirovini uvećanu vrijednost. Na taj način takvi zapisi i praksa postaju pokazatelji svojevrsne ovisnosti o cirkuliranju neke sirovine unutar uređenog društvenog sustava. Nadalje, može se pretpostaviti da su takve intervencije vrlo vjerojatno bile posljedica ekonomske krize sustava koji je posezao za određenim mjerama koje su takvo stanje mogle u najmanju ruku ublažiti.

\section{Transformacija prostora - transformacija svijesti}

Transformacija prostora zapravo predstavlja kontinuitet čovjekova utjecaja na krajolik. Takvi utjecaji mijenjali su se s generacijama, kulturama i prirodnim uvjetima. Svijest čovjeka o vlastitoj prolaznosti, precima i prošlim kulturama osobito je vidljiva i dugotrajna kada je njezin trag ostavljen u krajoliku. To indirektno podrazumijeva i ozbiljne intervencije u krajolik koje su tijekom nekoliko generacija pokušale zaustaviti vrijeme ponekad svjesno, no ponekad i slučajno. Takve pojave možemo promatrati kao sustavno korištenje istoga prostora bilo s jednakom ili izmijenjenom funkcijom. Kod ovih primjera razlozi „recikliranja“ su izuzetno složeni i tiču se raznih sfera ljudskog shvaćanja materijalnog i duhovnog, ovoga puta u prostoru.

U baštinskom smislu jedan od neprocjenjivih primjera upotrebe prostora kroz dugo razdoblje jest primjer Starogradskog polja na otoku Hvaru. Riječ je o grčkoj parcelizaciji polja koja je utemeljena još u 4. st. pr. Kr., a koristi se i danas, u tek neznatno izmijenjenom obliku. Naravno, odabir prostora ovisio je isključivo o prirodnim uvjetima na otoku i ograničenim plodnih površinama.

Na području Dalmacije mnogi su primjeri građevina koje se grade na temeljima starijih objekata, bez obzira na njihovu prvobitnu funkciju. 0 kontinuiranom korištenju prostora, drugim riječima, njegovu "recikliranju" svjedoče i brojni gradinski lokaliteti od kojih je većina korištena kroz više prapovijesnih i povijesnih razdoblja. Razlozi mogu biti dvoznačni, s jedne strane zaposjedanje istaknutih strateških položaja u krajoliku je posljedica odluka praktične prirode. 
SI. 11: Primjeri crkava i kapela izgrađenih na prapovijesnim grobnim humcima:

gore: sv. Nikola, Nin; (izvor: https://croatia.hr/hr-HR/Odredista/Mjesto/Zaton-(Zadar)?ZHNcNjYscFw3);

dolje: crkva sv. Ilije na Stazi sagrađena krajem 18. st. na ostacima prapovijesne gomile, Biokovo. (fotografirala: I. Miloglav).
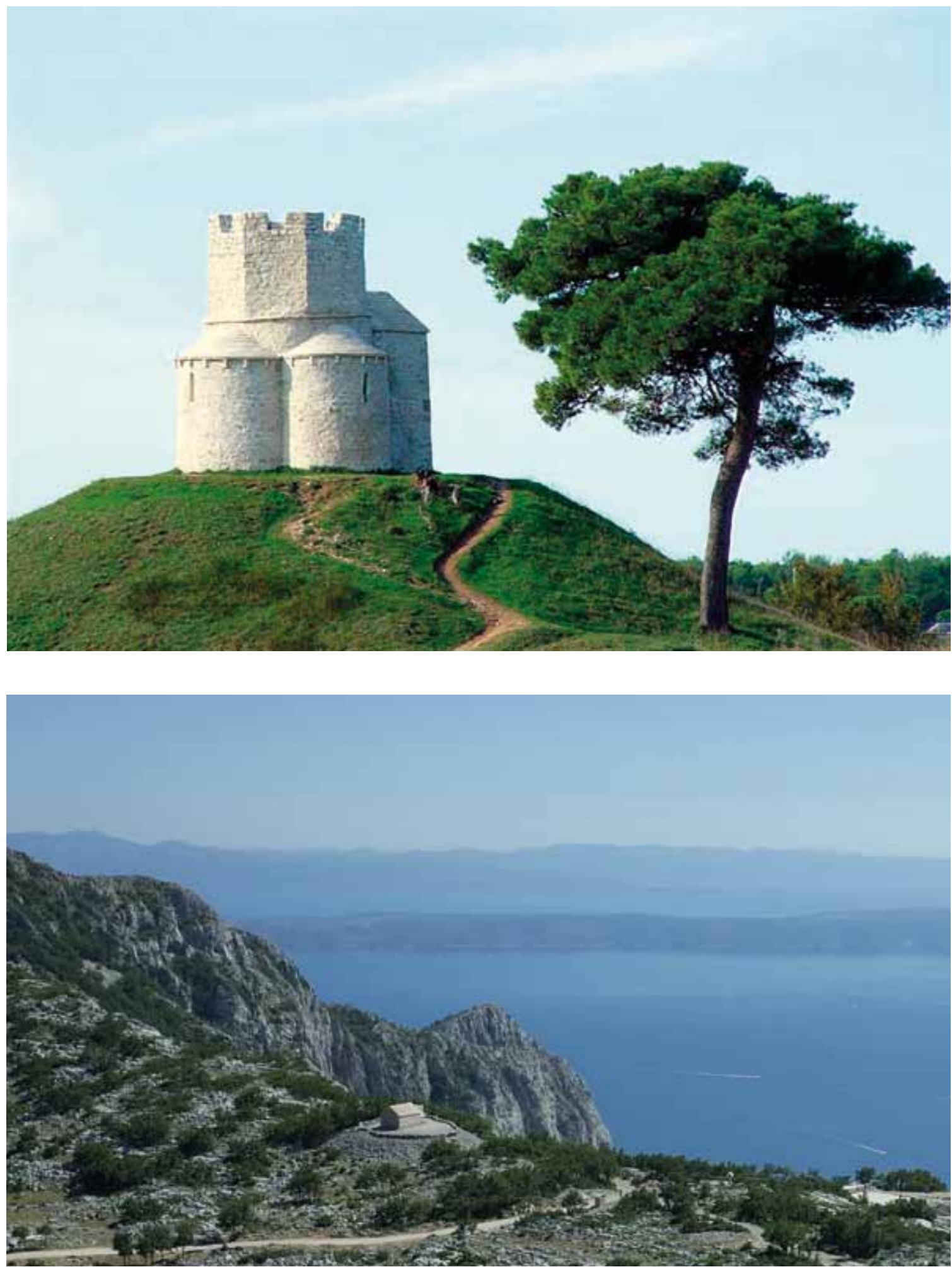
S druge strane, takvi su položaji vrlo često dio kolektivne svijesti o drevnosti položaja u krajoliku, a mogu biti i simbol održavanja kontinuiteta s precima (Babić 1991; Alduk 2010).

Ipak, u pozadini ponovne upotrebe prostora uglavnom su praktični motivi, a slični procesi događaju se i danas u sklopu interpolacija starih objekata u urbano gradsko tkivo. Takve intervencije u pozadini imaju baštinske motive, očuvanje i prezentaciju.

Neki od najstarijih kulturnih spomenika koji su izmijenili krajolik te ujedno predstavljaju svojevrsne spomenike prirode jesu prapovijesni humci ili tumuli. Riječ je o humcima načinjenima od zemlje ili kamena različitih dimenzija koji su podignuti iznad grobnih komora ili su nasipani na više grobova kako bi bili trajno vidljivo obilježje mjesta pokopa pojedinca ili većeg broja članova zajednice. Istraživanja su pokazala da su se naknadni ili sekundarni ukopi u već podignute tumule događali još tijekom prapovijesti, a ponovna upotreba istog položaja bilježi se i u prvim stoljećima povijesnoga doba, odnosno u ranoj antici (Šućur 2015). Naknadni ukopi u tumule, naravno, nisu fenomen koji se javlja samo u Dalmaciji već i diljem Europe. Primjerice na prostoru južne Nizozemske brojni prapovijesni tumuli odabrani su za mjesta na kojima se vršilo pogubljenje osuđenih na smrt, uglavnom vješanjem, a nerijetko su na tim mjestima izlagana i njihova tijela. Takvo tretiranje tumula od 14. pa sve do kraja 18. st. potvrđuju arheološki i povijesni izvori te toponimi (Meurkens 2010). No, kakvo su zapravo značenje takvi prapovijesni humci imali u srednjem vijeku? Pretpostavljaju se dva razloga odabira takvih mjesta: (1) zakoni i običaji su nalagali da mjesta pogubljenja i mjesta izlaganja tijela pogubljenih budu na osobito dobro vidljivom mjestu koje se može uočiti izdaleka, kako bi kažnjeni bili primjer ostalima; (2) kažnjenici su se morali odreći kršćanstva, odnosno odricali su se prava na kršćanski ukop pa su stoga „poganska“ mjesta priličila takvim kriminalnim pojedincima (Meurkens 2010: 7-8). To se može promatrati i tako da su ovim postupcima ujedno oskvrnuli i kažnjenika i mjesto. Istraživanja su autora (Meurkens 2010: 22) navela na zaključak da je demonizacija prapovijesnih grobalja započela otprilike stotinu godina nakon kristijanizacije, dakle između 11. i 13. st. Treća zanimljiva pojedinost, koja se ne može u potpunosti navesti kao razlog odabira humaka za egzekuciju jest podrijetlo običaja izlaganja kriminalaca, koje vuče korijene još od drevnih, germanskih običaja.

Međutim, postoji i potpuno drukčiji tip prenamjene takvih mjesta. Diljem Europe tijekom srednjega vijeka na vrhu, često najvećih, prapovijesnih grobnih humaka izgrađene su kapele ili manje crkve (sl. 11). Odabir položaja za gradnju može biti u vezi s dominantnom lokacijom u odnosu na krajolik, no pretpostavlja se i da su graditelji bili svjesni da humci na kojima su podigli kršćansku kapelu leže na umjetno stvorenoj konstrukciji iz drevne prošlosti čija je funkcija bila sakralne, „poganske“ prirode. Razlog postavljanja jakog kršćanskog elementa na vrh, još uvijek u svijesti memoriranog, poganskog mjesta, može se dovesti u vezu s ranije navedenim primjerima s područja sjeverne Europe. Naime, postavljanje kršćanskih titulara, kapela i crkava na mjesta s izrazitim poganskim obilježjima nije nepoznanica, te se koristi kao svojevrsna preventivna mjera zabilježena još u naputku pape Grgura I. Velikog iz 601. godine ${ }^{7}$ (Belaj 2009: 84; Belaj \& Belaj 2013; Belaj \& Belaj 2014). Takvo zaposjedanje starih položaja svojevrsna je prenamijena ili ponovna upotreba prostora ili religijska „reciklaža“.

\footnotetext{
7 ... hramove idola [misli se: poganskih bogova] kod toga naroda ne treba uništiti, nego treba uništiti idole u njima, blagosloviti vodu i njome poškropiti rečene hramove, podići oltare i postaviti relikvije. Jer, ako su hramovi dobro izgrađeni, oni će po naravi stvari promijeniti štovanje vragova u službu istinitoga Boga; da bi narod, vidjevši da njihovi hramovi nisu razrušeni, uklonio zablude iz svojih srdaca te, prepoznajući i štujući istinitoga Boga, njemu se s vremenom, prema navici, utjecao. I jer su se navikli za žrtve demonima klati mnoga goveda, potrebno je to promijeniti u bilo kakvu svečanost, kao što je dan posvećenja ili rođendan svetih mučenika čije su relikvije ovdje smještene, neka si naprave kolibu od granja drveća kraj tih crkava koje su preuređene iz hramova i neka zdušno proslave gozbenu svečanost te odsada ne žrtvuju životinje đavlu, nego neka na slavu Božju u svojoj gladi životinje kolju i Darovatelju svega za sitost svoju hvalu daju... (preuzeto iz Belaj 2009: 84-85).

8 O fenomenu zaposjedanja prostora i njegove sakralizacije na ovim prostorima bavila se nekolicina autora (Pleterski 1996; Belaj 2009; Belaj \& Belaj 2014).
} 
Na kraju ćemo navesti nekoliko primjera tzv. simboličkog recikliranja iako se prethodno predstavljena tema može djelomično razmatrati i kroz ovo poglavlje. Postoji čitav niz primjera kada ponovna upotreba predmeta postaje dijelom nekog rituala ili je ona isključivo simbolička. Takve su aktivnosti gotovo svakodnevica, a ponekad zaboravljamo da su dio i suvremenog života i odnosa prema stvarima (npr. darovi i različite vrste predmeta koji predstavljaju uspomene, porculanske figure, značke, obiteljske fotografije i sl.). U tim procesima glavnu ulogu imaju predmeti koji vrlo često ne pripadaju razdoblju u kojemu im je pripisana simbolička vrijednost, odnosno njihov „datum proizvodnje“ vjerojatno je mnogo stariji, a takvi predmeti postaju i svojevrsne memorabilije. Razlozi čuvanja, tj. simbolične upotrebe nisu nikada jednostavni kao ni veza između čovjeka i predmeta, odnosno onoga što on simbolizira.

Ne postoji predmet koji je pronalažen toliko često u najrazličitijim okolnostima simboličke prirode kao što su to keramičke posude ili njihovi ulomci, o čemu svjedoči niz etnografskih i arheoloških izvora (Smith 1989; Sterner 1989; Deal \& Hagstrum 1995; Gosselain \& Livingston Smith 2005; Kreiter 2007). Prema tim podacima posuda predstavlja svojevrsnu personifikaciju ljudskog tijela izgrađenog od tla od čega su se zadržali i nazivi za njezine dijelove (npr. vrat, rame ili trbuh posude), a životni vijek posude metafora je za životne cikluse čovjeka. U tom smislu posude odražavaju kontinuitet i identitet, simboliziraju rađanje života, dok razbijene posude simboliziraju smrt.

U arheološkom kontekstu cjelovite keramičke posude uglavnom se pronalaze u grobovima i važan su dio pogrebnih običaja i rituala u gotovo svim razdobljima prošlosti. Osim na grobljima, keramičke posude te osobito polomljene posude imaju važnu ulogu kao dio svakodnevnih rituala unutar ili uz naselja. Iz etnografskih izvora znamo da se u zajednicama južnoga Meksika oštećene ritualne posude i njihovi ulomci skupljaju i čuvaju oko kućnih oltara (Deal \& Hagstrum 1995: 118). Sličan običaj zabilježen je i u plemenu Gurensi u Africi (sjeveroistočna Gana). Tamo se na brojna svetišta, odnosno oltare predaka, na koja se odlažu razne prinesene žrtve, postavljaju ulomci razbijenih keramičkih posuda. Oni štite prinesenu žrtvu te prema njihovu vjerovanju keramički ulomci pojačavaju osjećaj duhovnosti i simbolike zbog sveprisutnog utjecaja i povezanosti s tlom (zemljom) koje se nalazi u svim aspektima takvih zajednica (Smith 1989: 61, fig. 4).

No, važnost keramičkih posuda utoliko je veća kada pogledamo mnoge primjere njihove reciklaže također zabilježene u etnografskim izvorima. Riječ je o recikliranju ulomaka keramičkih posuda koji su usitnjeni i iskorišteni kao sirovina (grog), tj. izmiješani su u glinoviti materijal od kojega su ponovno izgrađene nove posude. Prema pogrebnim običajima pojedinih plemena u južnoj Americi nakon smrti osobe sve pokojnikove posude bivaju razbijene, a jedan dio ulomaka odabire se za pripremu groga (DeBoer 1974: 336). Primjeri iz zapadne Afrike govore o sličnoj praksi u živim zajednicama gdje je zabilježeno da npr. nakon smrti osobe, bliska rodbina razbija posudu preminuloga, te priprema grog koji ugrađuje u novu posudu čime se održava povezanost obitelji s preminulim (Smith 1989: 61; Sterner 1989: 458 prema: Deal i Hagstrum 1995: 122; Sterner 1989, prema Kreiter 2007: 132). U zajednicama Fulani/Gurma (Burkina Faso), Namai Somono (Mali), Songhaya i Zarma (Nigerija) lončari recikliraju arheološke keramičke ulomke u obliku groga, a to objašnjavaju tvrdnjom da upotrebom komadića drevnih posuda stvaraju vezu s precima koji su znali kako napraviti čvrstu posudu (Gosselain \& Livingston Smith 2005: 41).

Grog se često ugrađivao u keramičke posude tijekom prapovijesti (sl. 12), a istraživanja su pokazala da premda je grog imao i svoju funkciju u proizvodno-tehnološkom i upotrebnom smislu, to nije uvijek bio slučaj, odnosno nije bio jedini razlog njegove upotrebe (Plog 1980; Gamble 2007; Kreiter 2007). Srodne simboličke motive recikliranja, zabilježene u etnograf- 
skim izvorima, možemo pretpostaviti i za prapovijesne zajednice koje su živjele na tlu Europe. Takve prakse ukazuju na određeni kontinuitet u memoriji, izravnu vezu s precima te prenošenje tradicije, posebice u društvima koja ne zapisuju svoju prošlost (Chapman 2000: 351; Brück 2006; Chapman \& Gaydarska 2006; Kreiter 2007).

Vrlo zanimljiv primjer u sklopu simboličkog recikliranja tiče se jednog, specifičnog predmeta cipela. Tijekom 18. i 19. stoljeća u Engleskoj je postojala neobična praksa skrivanja istrošenih i starih cipela na različite, nekonvencionalne lokacije u objektima, uglavnom zgradama. Tijekom 20. i 21. stoljeća otkriven je velik broj takvih cipela od kojih su mnoge završile u muzejima. Provedeno istraživanje (Houlbrook 2013) pokazalo je da tzv. „skrivene“ cipele imaju vrlo složenu biografiju, a autorica dovodi u pitanje i aktualnost kategorije tzv. „vrijednog smeća“ te podrijetlo ove neobične prakse dovodi u vezu s ritualnim recikliranjem. Prema istraživanjima $97,81 \%$ cipela je iznošeno i dotrajalo, njih $26,2 \%$ otkriveno je unutar ili uz dimnjak, ognjište ili peć dok je 22,86\% cipela pronađeno ispod podova, iznad stropa ili u potkrovlju (Eastop 2006: 246, prema Houlbrook 2013: 104). Autorica odabir takvih lokacija povezuje s njihovom zajedničkom karakteristikom, a to je liminalnost (granična zona, odnosno rubni prostor u kojemu se prelaze okviri društvenih struktura). Simbol cipele, prema arheološkim, povijesnim, etnografskim i ikonografskim izvorima sadrži određeno ritualno značenje te autorica (Houlbrook 2013: 105-107) smatra da stare cipele nisu odabirane zato jer više nisu bile nosive već da su upravo stare i iznošene cipele stekle određenu vrijednost radi koje su bile odabrane za skrivanje. Pravo značenje i svrha skrivanja pretpostavlja se i smatra da je riječ o svojevrsnoj zaštititi koja se postavlja na tzv. granična mjesta podložna utjecaju „zlih sila“. Bez obzira na tumačenja svrhe „skrivanja“ vidimo izvanredan primjer kako životni vijek cipele prelazi nekoliko ciklusa od upotrebne vrijednosti preko gubitka te vrijednosti i subjektivne transformacije u novi sustav pri čemu predmet iz konteksta smeća biva vraćen u život i recikliran kao ritualni objekt.

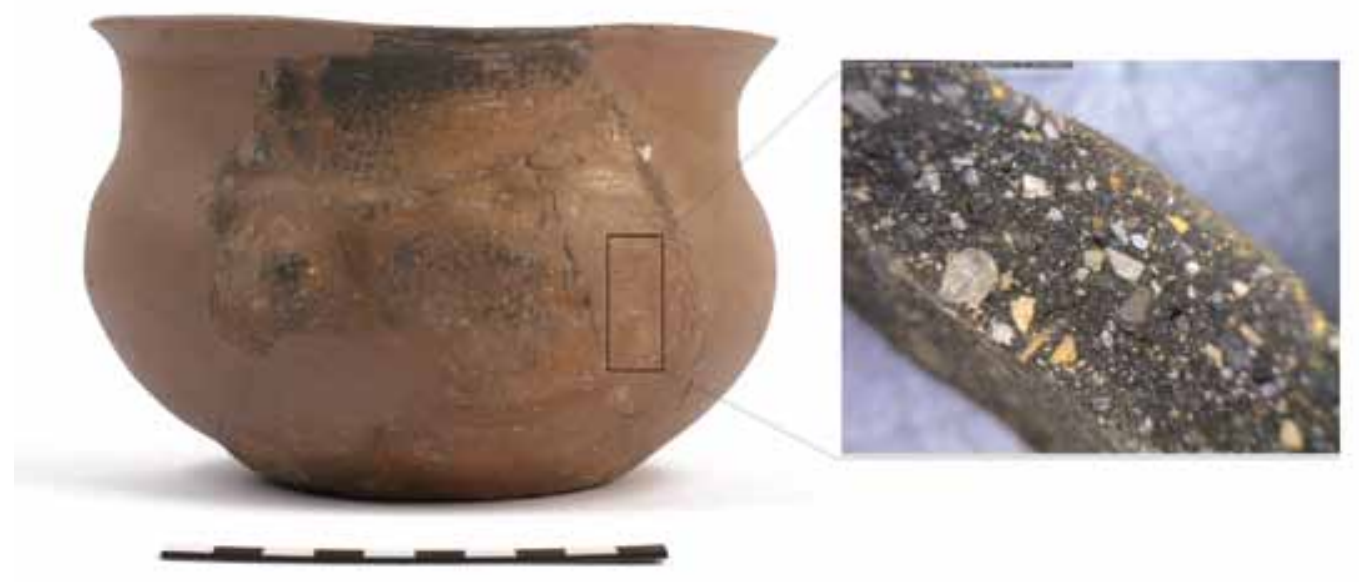

SI. 12: Presjek keramičkog ulomka posude s vidljivim zrnima groga s nalazišta u sjevero-zapadnoj Hrvatskoj, kasno brončano doba (fotografirali: H. Jambrek i A. Kudelić). 
SI. 13: Kamene sjekire iz mlađeg kamenog i bakrenog doba iz zbirke Pečornik (fotografirao: I. Krajcar, Arheološki muzej u Zagrebu).

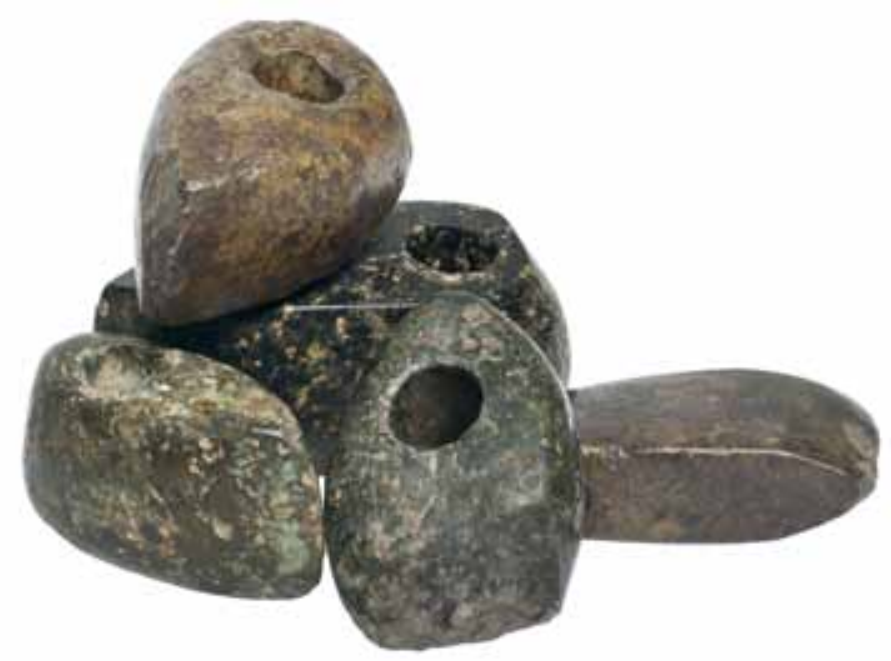

Još je jedan primjer prema kontekstu nalaza i svrsi polaganja, odnosno skrivanja, sličan praksi skrivanja cipela, no ovdje se radi o mnogo dugovječnijoj biografiji predmeta. Riječ je praksi iz dvadesetog stoljeća i polaganju prapovijesnih kamenih sjekira (narodni izrazi: kamene strele, strelni kamen ili strele) u pragove kuća i potkrovlja. Prema etnografskim izvorima kamene sjekire na području sjeverozapadne Hrvatske imale su nadnaravnu moć, osobito u zaštiti od udara groma, u liječenju stoke, zaštiti od bolesti, nesreće i uroka (Belaj 1998; Šimek 2010: 139). Ponekad bi se kamene strele ugrađivale u zid seoske kuće kamo ju je ugradio netko od predaka, vjerujući u njezinu magičnu moć te bi se ona s pažnjom prenijela u novu kuću kako zaštita doma ne bi bila prekinuta (Vuković 1960; Šantalab 1996: 27, preuzeto od: Šimek 2010: 141). Taj običaj karakterističan je za područje Hrvatskoga zagorja o čemu doznajemo iz navedenih etnografskih izvora, ali i prema brojnim nalazima prapovijesnih kamenih sjekira upravo s toga područja (većina kamenih sjekira čuva se u Arheološkom muzeju u Zagrebu; sl. 13). Slični običaji zabilježeni su i diljem Europe, a postoje i dokazi da je takva praksa, „recikliranja“ kamenih sjekira i njihova ponovna simbolička upotreba, mnogo starija. Poznato je da su u razdobljima antike i srednjega vijeka na širem području Europe prapovijesne kamene sjekire opisivane kao magični predmeti koji su sadržavali moć zaštite (Šimek 2010: 142-14). Zanimljiv je nalaz kamene sjekire otkrivene u bedemu iz kasne antike u Lepoglavi (Balen Letunić 1981) ili pak sjekire iz mlađega kamenog i bakrenog doba često pronađene u kontekstu brončanodobnih objekata i naselja.

Mjesta na koja se takvi predmeti polažu ili skrivaju, kao i u slučaju razmatranja simbolike odabira mjesta skrivanja cipela (Houlbrook 2013) predstavljaju tzv. granična mjesta (prag, potkrovlje, zid ili bedem). Iako nikada nećemo u potpunosti razumjeti takve običaje, ostaje nam artefakt kao fascinantan dokaz cirkuliranja odnosno recikliranja predmeta kroz vrijeme i prostor u istom ili djelomično izmijenjenom obliku i funkciji čije krajnje odredište vjerojatno još nije dosegnuto. 
U završnom dijelu teksta kratko ćemo se osvrnuti i na tzv. suvremene kulture recikliranja koje čine etničke zajednice poput Roma i egipatski pripadnici zajednice Zabbaleen (egipatski arapski: ljudi od smeća).

Romsko stanovništvo poznato je po svojim skupljačkim aktivnostima koje čine dio njihove tradicije, no skupljanje metalnog otpada i trgovina reciklažnim otpadom za njih je osim tradicije i simbol ekonomske neovisnosti. Zanimljiv je društveno-hijerarhijski sustav u kojemu se takvo skupljanje i trgovina provode (sl. 14). Odabir takvog načina života potpuno je neovisan o ideologijama suvremenog poimanja recikliranja i globalne osviještenosti o očuvanju okoliša. Za takve je zajednice to način života na koji polažu pravo prvenstva te ga štite njegujući tradiciju i prenoseći je na mlađe generacije.

Pripadnici zajednice Zabbaleen (egipatski arapski: ljudi od smeća) u Egiptu, na području grada Kaira, bave se skupljanjem smeća od četrdesetih godina dvadesetoga stoljeća. Rastuću zajednicu čini između 50 i 70 tisuća ljudi koji uglavnom žive u prigradskim manjim selima (Mokattam ili Grad smeća jedno je od njihovih najvećih naselja). Zajednica skuplja smeće od vrata do vrata te od toga žive, a prema nekim podacima recikliraju čak $80 \%$ smeća u Kairu dok kompanije koje se bave skupljanjem smeća recikliraju tek 20 do 25\% otpada (https://en.wikipedia.org/wiki/ Zabbaleen). Oni otpad prenose kolima koja vuku magarci te ga odvoze u sela gdje otpad sortiraju, dok organski otpad daju svinjama koje uzgajaju. Tijekom godina Zabbeleen su prerasli u specifičnu i vrlo organiziranu te složnu zajednicu. Međutim njihova je egzistencija nedavno postala ozbiljno ugrožena kada su gradske vlasti u Kairu 2003. godine dodijelile godišnje ugovore

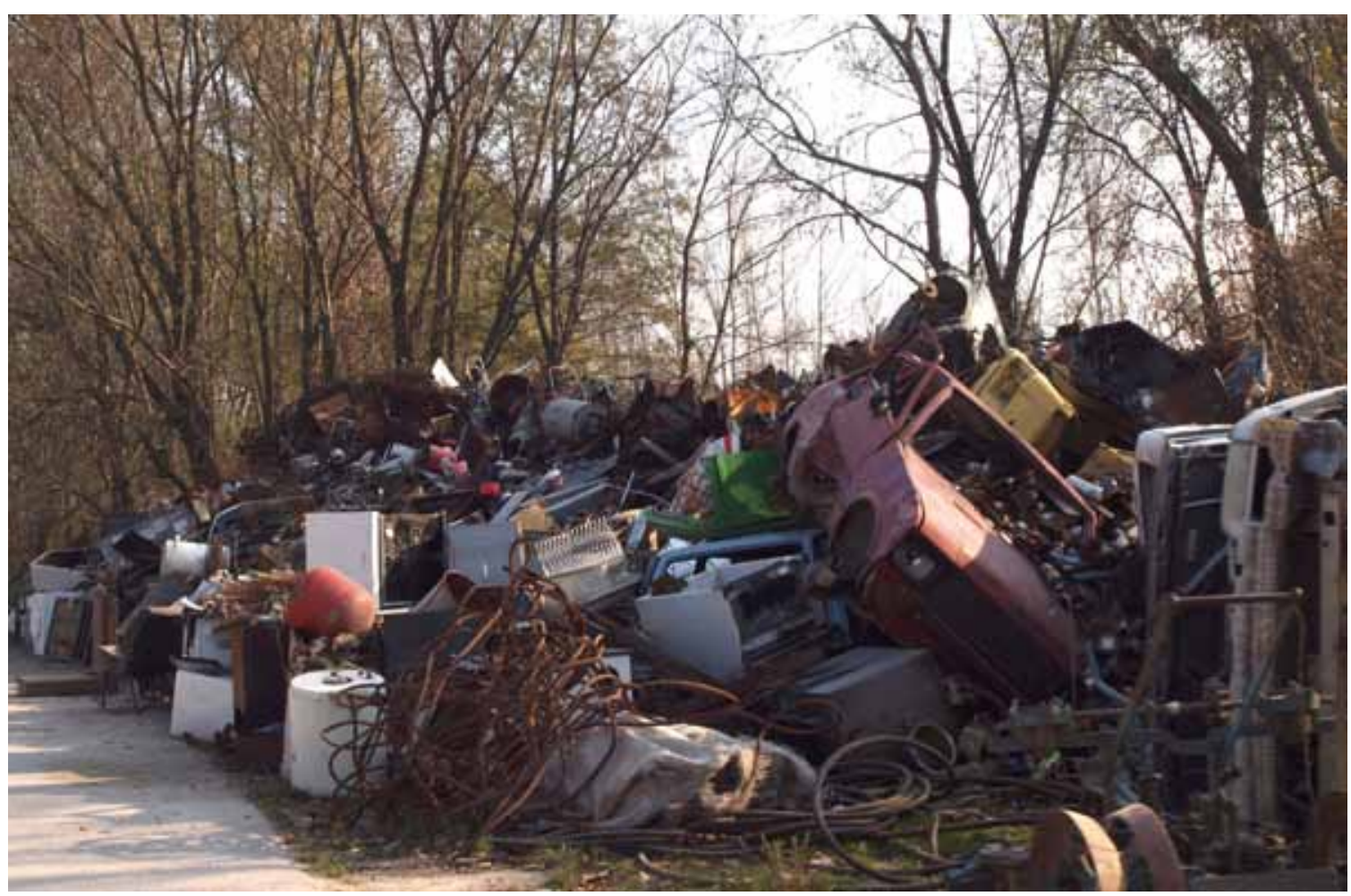

Sl. 14: Gomila skupljenog metalnog otpada ispred romske kuće, simbol statusa i moći vlasnika otpada, Podravina (fotografirala: F. Sirovica). 
od 50 milijuna dolara kompanijama za zbrinjavanje otpada. Na taj način društveno-ekonomska održivost zajednica Zabbaleen izravno je pogođena, a vlast ih je u ovome slučaju, prema njihovim navodima, potpuno ignorirala. Osim toga radi sanitetskih razloga zabranjen im je i uzgoj svinja koje desetljećima predstavljaju osnovnu komponentu u procesu recikliranja. Da stvar bude gora, gradska vlast je u proljeće 2017. godine najavila projekt koji podrazumijeva postavljanja više kioska u gradu gdje će se moći prodavati otpad (otkup otpada) što će prema inicijatorima ove ideje biti društveno, financijski i ekološki profitabilno za sve. Međutim, za pripadnike zajednice Zabbaleen to nije bila pozitivna vijest. Prema njihovim navodima to će bitno utjecati na njihove prihode, egzistenciju i način života, a gradsku inicijativu koja ih potiče da se uključe u trgovinu s pomoću kioska, ne prihvaćaju (https://www.egypttoday.com/Article/1/4027/From-trash-to-treasure-Egypt\%E2\%80\%99s-new-recycling-initiative-triggersdispute).

Ovo je primjer u kojemu je recikliranje postalo način života za čitavu zajednicu, a da pritom, iako je riječ o suvremenom dobu, nitko od njihovih pripadnika ne spominje ekološku osviještenost ili očuvanje okoliša. Gotovo paradoksalno, no riječ je o svojevrsnom sukobu new age grupacije koja zagovara recikliranje i ekološki je osviještena sa zajednicom koja više od sedamdeset godina reciklira $80 \%$ otpada jednog višemilijunskog grada.

\section{Zaključak}

Navedeni primjeri samo su manji dio aktivnosti koje su prepoznate kao praksa recikliranja, ponovne upotrebe ili prenamjene u životnom vijeku predmeta u prošlosti. Tragove takvih aktivnosti možemo prepoznati na arheološkom materijalu, dok je tumačenje pojedinih odluka vezanih uz procese recikliranja iz današnje perspektive ponekad teško razumjeti. No unatoč tome jasno je da je recikliranje u prošlosti bilo dio svakodnevice te da se provodilo gotovo rutinski, baš kao i danas. Može se reći da je fenomen recikliranja vremenski univerzalan, a razlozi su se uglavnom temeljili na održivosti, obnovljivosti resursa i sirovine, odnosno recikliranje je u osnovi bilo praktične prirode. Neki autori tumače praksu recikliranja kao ekonomiju ljudskog vremena i truda, i ograđuju se od recikliranja koje se promatra kao dio moralnog i etičkog izbora (Amick 2015:15), kao što se ono obično danas promatra. Recikliranje je ovisilo i o promjeni tehnologija i materijalima koji su s takvim promjenama povezani. Ono će se pojaviti i kada vrijednost nekom materijalu poraste u smislu rijetkosti ili teže dostupnosti sirovine ili npr. majstora koji je vladao znanjem o obradi materijala. Promjene u intenzitetu primjene prakse recikliranja npr. određenog materijala u prošlosti mogu ukazivati na specifična ekonomska zbivanja ili kulturološke transformacije. Tako na primjer tijekom izrazito stresnih ekonomskih perioda potreba za ponovnom upotrebom i recikliranjem iz sasvim ekonomskih razloga može rasti pogotovo kod neprivilegiranih i siromašnijih u zajednici (Wilson 1995: 127-128).

Iako je praktična priroda recikliranja u prošlosti bila primarna baš kao i danas, ne mogu se zanemariti primjeri gdje se praktičnost djelomično preklapa s ideološkim motivima i simboličkom prenamjenom pojedinih predmeta. Promatrajući takve prakse može se raspravljati o projiciranju subliminalnih poruka o povezanosti predmeta (kao djela prirode) i čovjeka tako što čovjek predmetu pripisuje posebne moći čime sam sebe postavlja u podređeni položaj. Možda takve prakse simboliziraju neraskidivu vezu čovjeka s prirodom i njegovu ovisnost o njoj.

Čovjek u prošlosti nije imao mnogo izbora, stoga je praktičnost uglavnom prevladala bilo da mi danas možemo protumačiti takve odluke ili su nam potpuno nejasne i ulaze u sferu mistike. Unatoč složenosti navedenih primjera i obrazaca recikliranja, kako danas tako i u prošlosti, dokazi o recikliranju na arheološkim artefaktima predstavljaju potencijalno vrijedne zapise o različitim sferama života u prošlosti. 


\section{Literatura}

Alduk, I. 2010. Srednjovjekovne tvrđave uz rijeku Cetinu. Ex Libris. Zagreb.

Amick, D. 2015. The recycling of material culture today and during the Paleolithic. Quaternary International 361. 4-20.

Andersson, E. 2003. Tools for Textile Production from Birka and Hedeby. Birka Studies 8. Stockholm.

Babić, I. 1991. Prostor između Trogira i Splita. Zavičajni muzej Kaštela. Kaštel Novi.

Balen, J. 2005. Vučedol - vinograd Streim. Hrvatski arheološki godišnjak 2. 43-45.

Balen Letunić, D. 1981. Kameno oružje i oruđe s područja Hrvatskog Zagorja, zbirka Pečornik. Godišnjak gradskog muzeja Varaždin 6. 5-16.

Barr S., Gilg A. \& Ford N. 2005. Defining the multi-dimensional aspects of household waste management: a study of reported behaviour in Devon Resources. Conservation and Recycling 45. 172-92.

Bass, G. F., Lledo, B., Brill, R. H. \& Matthews, S. 2009. Serçe Limani, Vol 2. The Glass of an Eleventh-Century Shipwreck. College Station. A\&M University Press. Texas.

Belaj, V. 1998. Hod kroz godinu. Golden marketing. Zagreb.

Belaj, J. 2009. Martin-Breg između poganstva i kršćanstva. Studia ethnologica Croatica, vol 21. 79-99.

Belaj, V. \& Belaj, J. 2013. Tragovi obrednoga organiziranja novoosvojenoga hrvatskog prostora u ranosrednjovjekovnoj hrvatskoj Dalmaciji. U: Kultovi, mitovi i vjerovanja u Zagori (ur. V. Kapitanović). Kulturni sabor Zagore, Filozofski fakultet u Splitu - Odsjek za povijest, Veleučilište u Šibeniku. Split. 89-107.

Belaj, V. \& Belaj, J. 2014. Sveti trokuti. Topografija hrvatske mitologije. Ibis grafika. Institut za arheologiju, Matica Hrvatska. Zagreb.

Bender Jørgensen, L. 2012. The introduction of sails to Scandinavia: Raw materials, labour and land. U: N-Tag Ten. Proceedings of the $10^{\text {th }}$ Nordig TAG conference at Stiklestad, Norway 2009 (ur. K. Sognnes, R. Berge \& M. E. Jasinski). BAR International Series 2399. Archeopress. Oxford.

Bender Jørgensen L. \& Grömer, K. 2012. The Archaeology of Textiles - Recent advances and new methods/Arheologija tekstila - suvremena dostignuća i novije metode. Godišnjak Hrvatskog restauratorskog zavoda 3. 45-67.

Bradley, R. 1988. Hoarding. Recycling and the Consumption of Prehistoric Metalwork: Technological Change in Western Europe. World Archaeology Vol. 20. 249-260.

Bradley, R. 2013. Hoards and the Deposition of Metalwork. U: Oxford Handbook of European Bronze Age (ur. A. Harding \& H. Fokkens). Oxford University Press. Oxford. 121-139.

Brück, J. 2006. Fragmentation, Personhood and the Social Construction of Technology in Middle and Late Bronze Age Britain. Cambridge Archaeological Journal 16/3. 297-315.

Chadwick, J. 1976. The Mycenaean World. Cambridge University Press. Cambridge.

Chapman, J. C. 2000. Fragmentation in Archaeology. Routhledge. Taylor and Francis Group. London, New York.

Chapman, J. C. \& Gaydarska, B. I. (ur.). 2006. Parts and wholes: fragmentation in prehisoric context. Oxbow Books. Oxford.

Deal, M. D. \& Hagstrum, M. B. 1995. Ceramic Reuse Behavior among the Maya and Wanka. Implications for Archaeology. U: Expanding Archaeology (ur. J. M. Skibo, W. H. Walker \& A. E. Nielsen). University of Utah Press. Salt Lake City. 111-125. 
Dean, R. B. 1995. Environmental fads and fallacies. Waste Management and Research 13 (3). 201-206.

DeBoer, W. R. 1974. Ceramic Longevity and Archaeological Interpretation: An Example from the Upper Ucayali, Peru. American Antiquity Vol. 39. No. 2. 335-343.

Dekker, K. 2014. What tools can tell The Bone Tools of Barcın Höyük. MA thesis. Free University of Amsterdam.

Dooijes, R. \& Nieuwenhuyse, O. P. 2007. Ancient repairs: techniques and social meaning. U: Konservieren oder Restauriere, Die Restaurierung griechischer Vasen von der Antike bis heute (ur. M. Benz \& U. Kästner). C. H. Beck. Munich. 15-22.

Dooijes, R. \& Nieuwenhuyse, O. P. 2009. Ancient Repairs in Archaeological Research: A Near Eastern Perspective. U: Holding It All Together: Ancient and Modern Approaches in Joining Repairs, and Consolidation (ur. J. Ambers, C. Higgitt, L. Harrison \& D. Saunders) Archetype Books. London. 8-12.

Douglas, M. 1984. Purity and danger: an analysis of concepts of pollution and taboo. Routledge. London.

Đuričić, A. 2014. The Construction and Usage of the Neolithic Oven: Experimental Archaeology. U: Archaeotechnology: Studying Technology from the Prehistory to the Middle Ages (ur. S. Vitezović \& D. Antonović). Srpsko arheološko društvo. Beograd. 257-277.

Eastop, D. 2006. Outside in: making sense of the deliberate concealment of garments within buildings. Textile 4(3). 238-55.

Eckelman, M. J. \& Chertow, M. R. 2009. Quantifying life cycle environmental benefits from the reuse of industrial materials in Pennsylvania. Environmental Science and Technology 43 (7). 2550-2556.

Franjić, A. \& Freestone, I. C. 2017. Iapodean Beads Inside and Out. In: Iapodes - the forgotten highlanders (ur. L. Bakarić). Exhibition Catalogue. Archaeological Museum in Zagreb. Zagreb. 135-139.

Freestone, I. C. 2015. The Recycling and Reuse of Roman Glass: Analytical Approaches. Journal of Glass Studies 57. 29-40.

Gamble, C. 2007. Origins and Revolutions. Human Identity in Earliest Prehistory. Cambridge University Press. Cambridge.

Gandy, M. 1994. Recycling and the politics of urban waste. St. Martin's Press. New York.

Gosselain, O. \& Livingston Smith, A. 2005. The source Clay selection and processing practices in Sub-saharan Africa. U: Pottery Manufacturing Processes: Reconstruction and Interpretation (ur. A. Livingstone Smith, D. Bosquet \& R. Martineau). BAR International Series 1349. Oxford. 33-47. Grömer, K. 2016. The Prehistoric Art of Textile Making. The development of craft traditions and clothing in Central Europe. Natural History Museum Vienna. Vienna.

Harding, A. F. 2000. European Societies in the Bronze Age. Cambridge University Press. Cambridge.

Hawkins, G. 2006. The Ethics of Waste: How We Relate to Rubbish. Rowman \& Littlefield. Lanham, MD.

Houlbrook, C. 2013. Ritual, Recycling and Recontextualization: Putting the Concealed Shoe into Context. Cambridge Archaeological Journal 23:1. 99-112.

Kaczmarek, B. 2016. „Recycling“ of raw materials 1500 years BC. Journal of Young Scientist, Volume IV. 39-42.

Karavanić, S. 2009. The Urnfield Culture in Continental Croatia, BAR International Series 2036. Oxford. 
Karageorghis, V. \& Kassianidou, V. 1999. Metalworking and Recycling in Late Bronze Age Cyprus - The evidence from Kition. Oxford Journal of Archaeology 18 (2). 171-188.

Keller, D. 2005. Social and Economic Aspects of Glass Recycling. U: TRAC 2004: Proceedings of the Fourteenth Annual Theoretical Roman Archaeology Conference, University of Durham (ur. J. Bruhn, B. Croxford \& D. Grigoropoulos). Oxbow. Oxford. 65-78.

Kopytoff, I. 1986. The cultural biography of things: commodization as process. U: The Social Life of Things. Commodities in Cultural Perspective (ur. A. Appadurai). Cambridge. 64-94.

Kreiter, A. 2007. Technological Choices and Material Meanings in Early and Middle Bronze Age Hungary. Understanding the active role of material culture through ceramic analysis. BAR International Series 1604. Oxford.

Lepore, P. 2010. Introduzione allo studio dell'epigrafia giuridica latina. Giuffré Editore. Milano. 79-80.

Marano, Y. A. 2011. La 'voce' degli antichi (Appendice II). U: Memorie dal passato di Iulia Concordia-un percorso attraverso le forme del riuso e del reimpiego dell'antico (ur. E. Petteno \& F. Rinaldi). Fondazione Colluto. Rubano. 141-160.

Martin, H. 1906. Silex a double patine. Bulletin de la Société Préhistorique de France 3 (7). 273274.

Mazăre, P. 2014. Investigating Neolithic and Copper Age Textile Production in Transylvania, U: Prehistoric, Ancient near Eastern and Aegean Textiles and Dress, an Interdisciplinary Anthology. Ancient textiles series Vol. 18 (ur. M. Harlow, C. Michel \& M-L. Nosch). Oxbow Book. Oxford \& Philadelphia. 1-42.

Medina, M. 2007. The World's Scavengers: Salvaging for Sustainable Consumption and Production. AltaMira. Plymouth, UK.

Meurkens, L. 2010. The late medieval/Early Modern reuse of prehistoric barrows as execution sites in the southern part of the Netherlands. Journal of Archaeology in the Low Countries 2 (2). Amsterdam University Press. Amsterdam. 5-29.

Muhly, J. D. 1992. The crisis years in the Mediterranean World: Transition or cultural disintegration. U: The Crisis Years: The $12^{\text {th }}$ Century BC. From Beyond the Danube to the Tigris (ur. W.A. Ward \& M. Sharp Joukowsky). Kendall/Hunt Publishing Company. Dubuque, Iowa. 10-26.

Olsen, S. L. 1984. Analytical Approaches to the Manufacture and Use of Bone Artifacts in Prehistory. Doctoral disertation. Institute of Archaeology. University of London.

Peña, T. J. 2007. Roman pottery in archaeological record. Cambridge University Press. Cambridge.

Pleterski, A. 1996. Strukture tridelne ideologije v prostoru pri Slovanih. Zgodovinski časopis 50. 163-185.

Plog, S. 1980. Stylistic variation in prehistoric ceramics. Design analysis in American Southwest. Cambridge University Press. Cambridge.

Rajković, V. (ur.) 2006. Posavska tradicijska drvena kuća, priručnik za obnovu. Ministarstvo mora, turizma, prometa i razvitka. Ministarstvo kulture. Zagreb.

Rasmussen, S. 2012. How Glass Changed the World, The History and Chemistry of Glass from Antiquity to 13th Century. Springer Briefs in Molecular Science.

Rathje, W. \& Murphy, C. 2001. The Rubish! The archaeology of garbage. University of Arizona Press. Tuscon.

Riley, M. 2008. From salvage to recycling - new agendas or same old rubbish? Area 40/1. 79-89.

Roberts, S., Sofaer, J. \& Kiss, V. 2008. Characterization and textural analysis of Middle Bronze Age Transdanubian inlaid wares of the Encrusted Pottery Culture, Hungary: a preliminary study. Journal of Archaeological Science, Vol. 35/2. 322-330. 
Schiffer, M. B. 1983. Toward the Identification of Formation Processes. American Antiquity 48 (4). 675-706.

Schiffer, M. B. 1987. Formation Processes of the Archaeological Record. University of New Mexico Press. Albuquerque.

Schiffer, M. B. 2000. Behavioral Archaeology, Principles and Practice. Equinox Publishing Ltd. London, Oakville.

Sidéra, I. 2013. Manufacturing bone tools: The Example of Kovačevo. U: Bioarheologija na Balkanu. Bilans i perspektive (ur. N. Miladinović-Radmilović \& S. Vitezović). Radovi bioarheološke sekcije Srpskog arheološkog društva. Beograd-Sremska Mitrovica. 173-178.

Silvestri, A. 2008. The coloured glass of Iulia Felix. Journal of Archaeological Science 35. 14891501.

Skibo, J. M. 2013. Understanding Pottery Function. Springer.

Smith, F. T. 1989. Earth, Vessels, and Harmony among the Gurensi. African Arts. Vol. 22/2. 60-65.

Smith, J. S. 1992-1993. The Pylos Jn series. Minos. Rivista de Filología Egea XXVII-XXVIII. 167259.

Sterner, J. 1989. Who is Signalling Whom? Ceramic Style, Ethnicity and Taphonomy amongst the Sirak Bulahary. Antiquity 63. 451-459.

Šantalab, D. 1996. Kamena strela. Muzejski vjesnik 18/19. Kumrovec. 25-28.

Šimek, M. 2010. „Kamena strela“ u srednjovjekovnoj utvrdi? Zbornik soboškega muzeja 15. 135-149.

Šućur, J. 2015. Ukapanje u prapovijesnim tumulima od kasne antike do novog vijeka Sv.1 i 2. Doktorska disertacija. Sveučilište u Zadru.

Urem-Kotsou, D., Stern, B., Heron, C. \& Kotsakis, K. 2002. Birch-bark tar at Neolithic Makriyalos, Greece. Antiquity 76. 962-967.

Vinski-Gasparini, K. 1973. Kultura polja sa žarama u sjevernoj Hrvatskoj. Radovi Filozofskog fakulteta. Zadar.

Vitezović, S. 2016. Bos and the bone spoon revisited: Spatula-spoons in the Starčevo culture. U: Southeast Europe and Anatolia in prehistory. Essays in honor of Vassil Nikolov on his $65^{\text {th }}$ anniversary (ur. K. Bacvarov \& R. Gleser). Universitätsforschungen zur prähistorischen

Archäologie Band 293 Aus der Abteilung für Ur- und Frühgeschichtliche Archäologie der Universität Münster. Verlag Dr. Rudolf Habelt GmbH. Bonn. 189-196.

Všianský, D., Petřik, J. \& Kolář, J. 2014. Continuity and changes of manufacturing traditions of Bell Beaker and Bronze Age encrusted pottery in the Morava river catchment (Czech Republic). Journal of Archaeological Science, Vol. 49. 414-422.

Vuković, J. 2015. Secondary use, Reuse and Recycling of Ceramic Vessels: Evidence from Late Neolithic Vinča. Arhaika 3. 111-126.

Vuković, S. 1960. Zapisi, oko 1960. Arhiva AO Gradski muzej Varaždin.

Wilson, D. C. 1995. The Analysis of Domestic Reuse in Historical Archaeology, U: Expanding Archaeology (ur. J. M. Skibo, W. H. Walker \& A. E. Nielsen). University of Utah Press. Salt Lake City. 126-140. 


\section{Elektronički izvori}

https://en.wikipedia.org/wiki/Zabbaleen (pristup: 28. 10. 2017.)

https://www.egypttoday.com/Article/1/4027/From-trash-to-treasure-Egypt\%E2\%80\%99snew-recycling-initiative-triggers-dispute (pristup: 28. 10. 2017.)

http://www.fzoeu.hr/hr/gospodarenje_otpadom/posebne_kategorije_otpada/ambalazni_otpad/ (pristup: 22. 10. 2017.)

http://mplan.hr/djelatnosti/bjelovar/reciklazna-dvorista-i-odlagalista-gradevinskog-otpada (pristup: 21.10.2017.)

http://www.dictionary.com/browse/recycle (pristup: 21. 10. 2017.)

https://discardstudies.com/2016/03/09/the-politics-of-recycling-vs-reusing/ (pristup: 21. 10. 2017.)

https://hr.wikipedia.org/wiki/Recikliranje(pristup: 21. 10. 2017.)

https://discardstudies.com/2016/03/09/the-politics-of-recycling-vs-reusing/ (pristup: 21. 10. 2017.)

https://commons.wikimedia.org/wiki/File\%3AScrap\%5E_Will_Help_Win._Don't_Mix_it_-_ NARA_-_533983.jpg; U.S. National Archives and Records Administration) [Public domain], via Wikimedia Commons (pristup: 20.10. 2017.)

Autor Sharon Mollerus - originally posted to Flickr as How Cool Is Writing, CC BY 2.0, httpscommons.wikimedia.orgwindex.phpcurid=7633385

https://croatia.hr/hr-HR/Odredista/Mjesto/Zaton-(Zadar)?ZHNcNjYsc (pristup: 20. 10. 2017.)

\section{Ostali izvori}

Hrvatska agencija za okoliš i prirodu, Zagreb 2017.

Plan gospodarenja otpadom RH, podaci za razdoblje od 2016-2022. godine. Narodne novine, broj 94/13. Vlada Republike Hrvatske (http://mzoip.hr/doc/-nacrt_prijedloga_plana_gospodarenja_otpadom_republike_hrvatske_za_razdoblje_2016-2022_.pdf)

Fond za zaštitu i energetsku učinkovitost. 